\title{
Competing scripts: The Introduction of the Roman Alphabet in Africa*
}

\author{
Helma Pasch
}

\section{Abstract}

The introduction of the Roman script since the turn of the $20^{\text {th }}$ century was the first attempt of mass alphabetization in Africa, and it has become the most important writing system. It was, however, not the first script on the continent. In Old Egypt and its successor states, writing systems were developed, transferred to other languages and modified, replaced by new systems, and occasionally became obsolete. In a number of northern and north-eastern African languages Latin replaced earlier scripts. Despite many efforts to alphabetize the population and graphize African languages only a few languages have become media of written communication and learning. For some languages, however, independent scripts were, some of which are used till today. The introduction of the internet enhanced the chances for the Latin script as a written medium for African languages. It is also the platform for a revival of the old scripts likeTifinagh and Ajami, and some of the independent African scripts.

\section{Introduction}

Since the pre-colonial and colonial discovery of the interior of Africa attempts have been made, above all by Christian missionaries, to graphize African languages. In many cases missionaries, researchers of various disciplines and colonial officers, alongside their official duties, pursued their philological and linguistic interests in African languages combined with pedagogic ambitions (cf. Löhr 1997:79).

Besides purely scientific interests, a major aim was to provide education to the local population groups in their own languages and enable them to read the Bible in these very languages. A further aim was enable them to improve their conditions of living ${ }^{1}$, participate successfully in the new export oriented economy of the colonial powers and become "modern" people (cf. Hair 1967). While colonial administrations often made the missionaries' activities difficult, they cooperated successfully in other cases (Samarin 1989b:162-212).

Today most African languages with a writing system use modified forms of the Roman or Latin ${ }^{2}$ alphabet. The majority of these writing systems were developed by Christian missionaries, who in cooperation with the colonial administrations tried to unify the writing systems.

Not seldom quite generally statements are made that French and Portuguese colonies were characterised by assimilationist rule with school education in French and Portuguese respectively from the first grade onwards. In British and Belgian territories indirect rule is said to have prevailed with teaching in the vernacular in the lower primary grades and a switch to English and French or Flemish as medium of instruction in the later primary grades. In the post-independence period anglophone countries continued to promote mother tongue education, francophone countries retained French as a medium of education. Albaugh (online) observes, however, that this distinction has not proven unambiguous, and that both British and French used intermediaries in Muslim areas. Nowadays language policies have changed considerably: francophone countries have started to introduce local languages as media of instruction. A striking example is Senegal, where presently more than $90 \%$ of adult the alphabetisation ${ }^{3}$ is carried out in national languages (Köpp 2003:146f). At the same time, some anglophone countries have replaced their mother tongue education by an English-medium instruction from the first grade, e.g. Ghana (Owu-Ewie 2006). 
Despite the engagement invested in alphabetization programs, a "print-rich environment" with a well developed reading culture and the "concomitant empowerment of the population" is not the normal situation (Hutchison 2006:22). In Africa by and large oral communication rather than written communication still prevails: it is the "continent of the spoken word, not written" 4 (Mayr 1998). This is true in particular with regard to African languages. They are used for only a relatively small number of newspapers and books. Moreover, book publications in African languages cover only a restricted set of genres: primarily novels and stories, proverbs, plays, but also history books and linguistic studies. Specialized technical texts are rare. Nevertheless, missionaries and NGOs continue to engage themselves in the development of African languages and alphabetization programs, and nowadays missionaries put the focus more on education and empowerment of the population than on evangelization.

Since its introduction, Roman script has played a decisive role for the development of education and literacy in basically all African countries, although it could not replace all prior writing systems. But while writing and print publications in African languages do not show the output desired, it appears that the internet offers more attractive conditions for effective written communication in African languages than books could ever do.

In this paper I will investigate the history of graphization of African languages in Latin script and the alphabetization of the speakers. The focus is on success and failures with regard to the use of African languages as means of written communication. Chapter 2 gives a short presentation of pre-colonial writing systems, in particular those which later competed with the Roman script, namely Amharic, Tifinagh and Ajami. In Chapter 3, I will discuss the introduction of the Roman script and the way it was adopted in different countries. Chapter 4 deals with the creation of several autochthonous scripts in several parts of West Africa. Chapter 5 discusses the use of African languages in the internet, which has been the platform for several attempts to revitalize some of the pre-Roman scripts. In Chapter 6 Sango is investigated as a case study for the history of graphization.

\section{Early autochthonous scripts}

It cannot be denied that the passionate introduction of the Roman script in the colonial era by Christian missionaries and colonialists meant the first graphization of many African languages as well as a first introduction of mass alphabetization. But the missionaries were not really the first people to bring "enlightenment" to the continent in form of written communication, and their programs to introduce Roman script were neither the first nor the last attempts to graphize African languages in Roman script.

In the olden days Greek and Latin scripts were used in Northern Africa, but there is no information that the Greeks or Romans made efforts to spread the use of their scripts. As a third script Punic was used, out of which the Berber script Tifinagh developed. By the end of the $7^{\text {th }}$ century CE all of these scripts were replaced within a fairly short time by the Arabic one (Haarmann 1990:414).

With regard to a number of languages in West, North-East and East Africa, the introduction of the Roman script under colonialism by the missionaries caused the replacement of the earlier scripts. Ge'ez and Amharic, Tigrinya and Oromo were written in the Ethiopic script, and in Ethiopia, there was a tradition of written literature for fifteen centuries (Baumgardt \& Bounfour 2000). Berber dialects were written in Tifinagh and in Arabic. Swahili, Somali, Hausa, Kanuri, Manding, Susu, Wolof and Fulfulde were written in adapted forms of the Arabic script, Ajami. For some of these 
languages, there is a competitive coexistence of the old and the new script with alternating "winners".

\subsection{Old Egyptian scripts}

Hieroglyphic, Hieratic and Demotic are the scripts of ancient Egypt. All of them distinguish between phonograms (sound symbols) and semograms (= idea writing) (Hieroglyphen-Info).

\subsubsection{Hieroglyphics}

Hieroglyphics, used for monumental writing, have been proved to be the oldest writing systems of the world (Mitchell 1999). Quite enthusiastic Theophile Obenga (1999/2000) calls Africa the "Cradle of Writing" and so does Tuchscherer (1999:55). It must, however, be considered, that only a small number of specialists mastered the art of reading and writing hieroglyphs. Nowadays hieroglyphs are only used for decorative inscriptions and touristic objects.

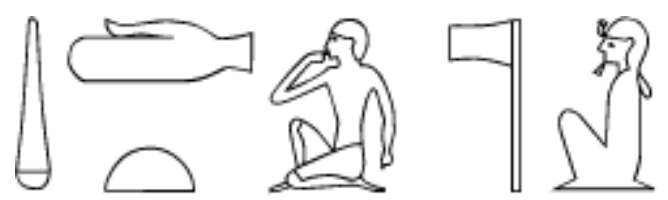

Source: http://www.omniglot.com/writing/egyptian hieratic.htm

\subsubsection{Hieratic script}

The Hieratic script is a simplified and abbreviated form of the hieroglyphic script, which allowed a higher speed of writing. It was designed more or less at the same time as the hieroglyphic script. But while hieroglyphs could be written both in rows and columns, from right to left and from left to right, the writing direction in Hieratic was initially vertical. By 2000 BCE it changed and was written exclusively from right to left in horizontal lines. Papyrus was the main medium of Hieratic texts, but the script was also used in carved or painted inscriptions.

The Hieratic script lasted for about 3.200 years, the earliest documents dating from about 2750 BCE, and its use ended in the 26th Dynasty. At the beginning the Hieratic script, which was hence not mastered only by specialists taught in school, was used for everyday purposes such as keeping records and accounts and writing letters. During the last 1.000 years of its existence its use was restricted to religious texts, secular texts now being written in Demotic. This corroborates with the etymology of the term 'hieratic' a borrowing from Greek meaning 'priestly' (Encyclopaedia of the Orient, online).

Hieratic glyphs and the hieroglyphs they evolved from

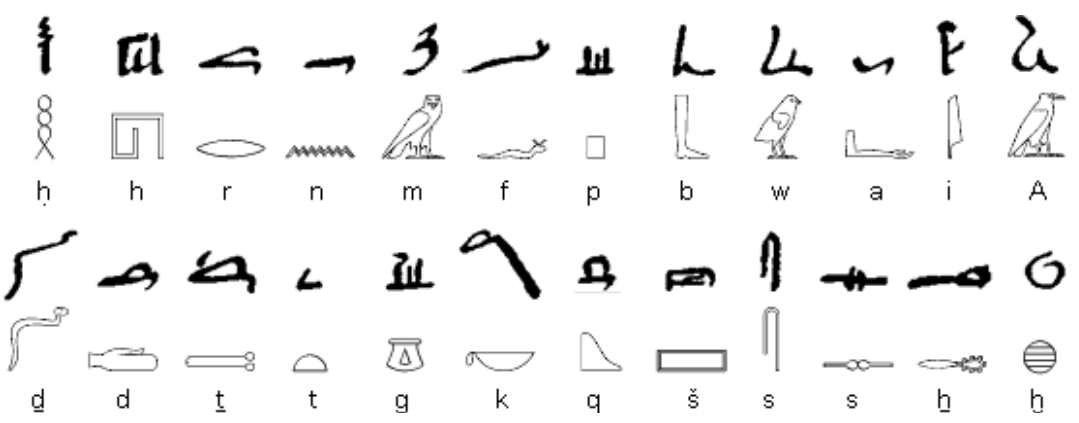

Source: http://www.omniglot.com/writing/egyptian_hieratic.htm 


\subsubsection{Demotic Script}

The Demotic or popular script developed from the northern variety of Hieratic during the $25^{\text {th }}$ Dynasty. Whereas Hieratic characters generally look quite similar to their Hieroglyphic counterparts, the similarities of Demotic characters to Hieroglyphics are barely recognizable. Demotic is the most cursive script developed in Egypt which not only contained both phonetic signs and determinatives, but in addition many of the signs were ligatures of two or more such signs (Johnson 2000:1). Several types of new phonetic symbols were introduced (UMich Papyrus Collection, online). Around 660 BCE it replaced Hieratic for secular writing, i.e. for business, legal and scientific matters and literature. The Hieratic script then was only used for religious purposes (Encyclopaedia of the Orient, online), but religious texts were also written in Demotic. During the $26^{\text {th }}$ Dynasty Demotic became the preferred script at court, but during the $4^{\text {th }}$ century it was gradually replaced by the Greek-derived Coptic alphabet. The most recent example of writing in the Demotic script dates from $425 \mathrm{CE}$.

The name Demotic was given by Herodotus and means 'the people's writing' referring to the fact that many Egyptians could read it. The Egyptians themselves called it sekh shat ('writing for documents'). It was written almost exclusively from right to left in horizontal lines and mainly in ink on papyrus, but Demotic inscriptions on wood and stone are also known. During the Ptolemaic period it was regularly carved in stone. The most famous example of this is the Rosetta Stone, inscribed with texts in the Hieroglyphic script, Greek and Demotic and was a key to the decipherment of Ancient Egyptian scripts (Ager, online).

Demotic glyphs representing single consonants

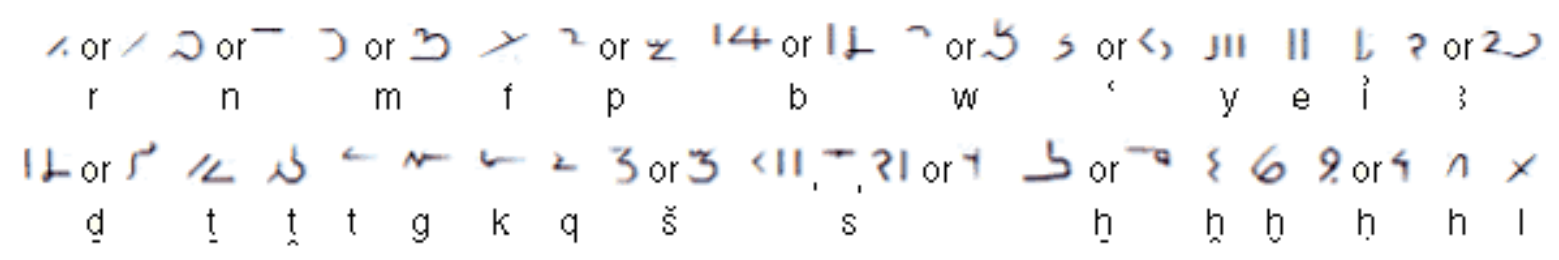

Source: http://www.omniglot.com/writing/egyptian demotic.htm

\subsubsection{Coptic}

The Coptic alphabet is a variety of the Greek alphabet. It came into being during the $3^{\text {rd }}$ century BCE after the Greek conquest of Egypt and the subsequent spread of Christianity. Coptic uses all the Greek characters and in addition six extra letters to represent Egyptian sounds non existent in Greek. The extra letters are borrowed from the Demotic script. In contrast to Hieratic and Demotic but like Greek, Coptic is written in horizontal lines from left to right (UMich, online).

The name 'Coptic' is derived from the Greek word for Egyptian: Aigyptioi which became Qibt in Arabic and then was latinised to become Copt (Ager, online). 


\begin{tabular}{|c|c|c|c|c|c|c|c|c|c|c|}
\hline alpha & B B & g5 5 & $\Delta \underset{\text { delta }}{\Delta}$ & $\boldsymbol{\epsilon} \epsilon$ & $\underset{s 00}{\tilde{\tau}}$ & Z Z & $\begin{array}{c}\mathrm{H} \mathbf{~} \\
\text { eeta }\end{array}$ & $\boldsymbol{\theta} \boldsymbol{\theta}$ & $\begin{array}{l}11 \\
\text { iota }\end{array}$ & $\begin{array}{l}\text { K K } \\
\text { kappa }\end{array}$ \\
\hline 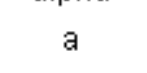 & $b, v$ & $\mathrm{~g}, \mathrm{gh}, \mathrm{ng}$ & th, d & . & . & 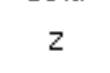 & ee & th, $t$ & i, $y$ & $k$ \\
\hline [a ] & {$[b, v]$} & {$[g, \eta]$} & {$[a, d]$} & {$[\varepsilon, \mathrm{e}]$} & & [z] & [i: ] & [ $\left.{ }^{\theta}\right]$ & {$[I, j]$} & [k] \\
\hline$\lambda \lambda$ & $\mu u$ & $14 \mathrm{~N}$ & $z z$ & 00 & $\prod \pi$ & $P p$ & $\mathrm{C} \mathrm{C}_{\mathrm{C}}$ & $\pi$ & $\Upsilon \gamma$ & $\Phi \phi$ \\
\hline lamda & mei & nei & eksee & 0 & pee & ro & seema & tav & epsilon & fei \\
\hline I & $\mathrm{m}$ & $n$ & $x$ & 0 (short) & $p$ & r & $s$ & $t, d$ & $v, u, y$ & $f$ \\
\hline [1] & {$[\mathrm{m}]$} & {$[n]$} & [ks ] & [0] & {$[p]$} & {$[r]$} & [s] & {$[t, d]$} & {$[\mathrm{v}, \mathrm{u}, \mathrm{I}]$} & {$[f]$} \\
\hline$X x$ & IS U & $\omega$ & (1) $\omega$ & $9 \mathrm{c}$ & L & 2 & 60 & & C & \\
\hline kai & epsee & 0 & shai & fai & khai & horee & cheema & tee & janja & jinkim \\
\hline $\mathrm{h}, \mathrm{kh}$ & ps & o (long) & sh & f & $\mathrm{kh}$ & $\mathrm{h}$ & ch & tee & 1. j & \\
\hline$\left[k, \int, x\right]$ & {$[\overline{p s}]$} & [0: ] & [ ] ] & {$[f]$} & {$[x]$} & {$[\mathrm{h}]$} & [t] ] & [ $\mathrm{ti}]$ & $[g, d\}]$ & \\
\hline
\end{tabular}

Source: http://www.omniglot.com/writing/coptic.htm

\subsection{Meroitic hieroglyphs}

In the Cushitic kingdom of Meroe, which stretched from Nubia in the Nile Valley to near today's Khartoum, the Eyptian hieroglyphic writing system was the only script until 200 BCE (Bechhaus-Gerst 1996:28) It had some influence on the modified hieroglyphic Meroitic script, which was developed only then, at the last stage of the kingdom around 200 BCE. According to Rilly (2004) it was used until 420 CE, when the Meroitic language gave way to Nubian. Bechhaus-Gerst, however, postulates that the Meroitic script was used even after the end of the kingdom of Meroe.

After the Egyptian hieroglyphics, the Meroitic writing system is the second-oldest in Africa, and it constitutes the first graphization of a local language (Bechhaus-Gerst 1996:28). It was in several ways superior to the Egyptian system. The people of Meroe reduced the multitude of hieroglyphic signs to 23 basic signs and created an alphabet. Again, unlike the Egyptian system, this alphabet also included vowel sounds, a great improvement over the hieroglyphic system, as well as a sign marking the division of words, an uncommon feature in ancient writing (Grzymski 1983:22f). One of the most striking things about the Meroitic script is the inclusion of a distinct set of traditionally termed 'syllable' signs. The widely used cursive version of which some 1278 texts are known was mainly used on stelae and ostraca ${ }^{5}$ while the hieroglyphic form was used monumentally (Rowan 2006:131).

In 1909 the script was deciphered by Griffith, but the language behind it remains a problem; only a few words are understandable (Bechhaus-Gerst 1996:28). 


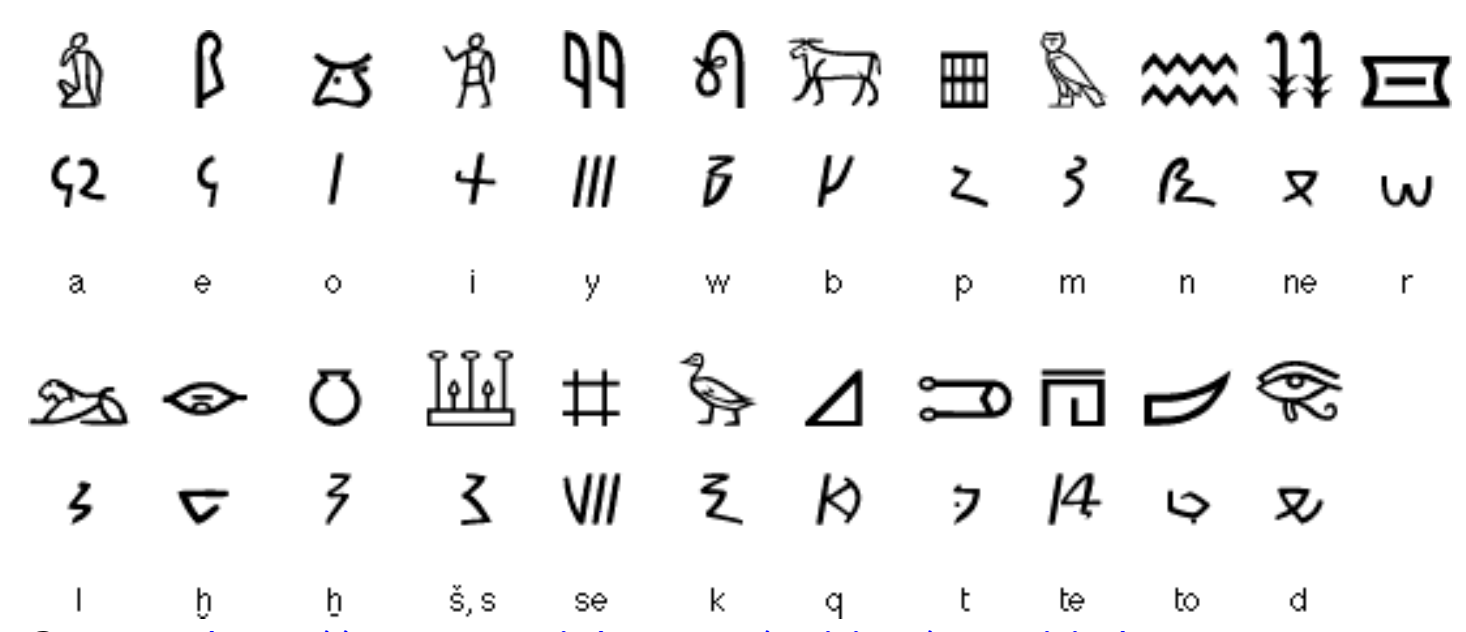

Source: http://www.omniglot.com/writing/meroitic.htm

\subsection{Nubian alphabet}

Old Nubian or Nobiin, the language of the Christian Sudan in the medieval period (Browne 1989:IX) is the only living African language which was written before the common era. It was spoken in a highly unusual situation of multilingualism where four languages were used for written communication: Nobiin, Greek, Coptic and Arabic. Greek and Coptic were the media of international correspondence since the $5^{\text {th }}$ century CE (Bechhaus-Gerst 1996:28f).

The Coptic script was introduced to the Nubian successor kingdoms of Meroe with Christianity. The church encouraged literacy in Nubia through its Egyptiantrained clergy in its monastic and cathedral schools. As a language of liturgy Greek eventually gave way to Old Nubian or Nobiin, which was written in an adapted form of the Coptic script, enlarged by elements from Old Meroitic.

It is often assumed that this Old Nubian script was used from the $8^{\text {th }}$ to the $11^{\text {th }}$ century by Christian communities in Egypt. The adoptation of Merotic symbols, however, is difficult to explain in view of the time depth between the alleged extinction of the Meroitic script and the creation of the old Nubian script. The evaluation of documents written in Meroitic, which can only be done after that the language has been deciphered may give an answer to this question (Bechhaus-Gerst 1996:29).

In the $8^{\text {th }}$ century CE the king of Nubia received the first letters written in Arabic, and in the $12^{\text {th }}$ century Arabic had replaced Coptic as international language. By that time first borrowings from Arabic are documented in Nobiin texts. Only in Lower Nubia the language was able to maintain its function as a written means of communication next to Arabic until the end of the $15^{\text {th }}$ century. From the $16^{\text {th }}$ century on, however, Arabic was the only written language in the area of the present northern Sudan (Bechhaus-Gerst 1996:31).

Today the Nubian language Kenuzi-Dongola spoken in Sudan and Egypt, is written in either Latin or Arabic script (Languages of the World, online), but three active proposals have been made for a unique script of Nubian: the, the and the Old Nubian alphabet (Hashim 2004). 


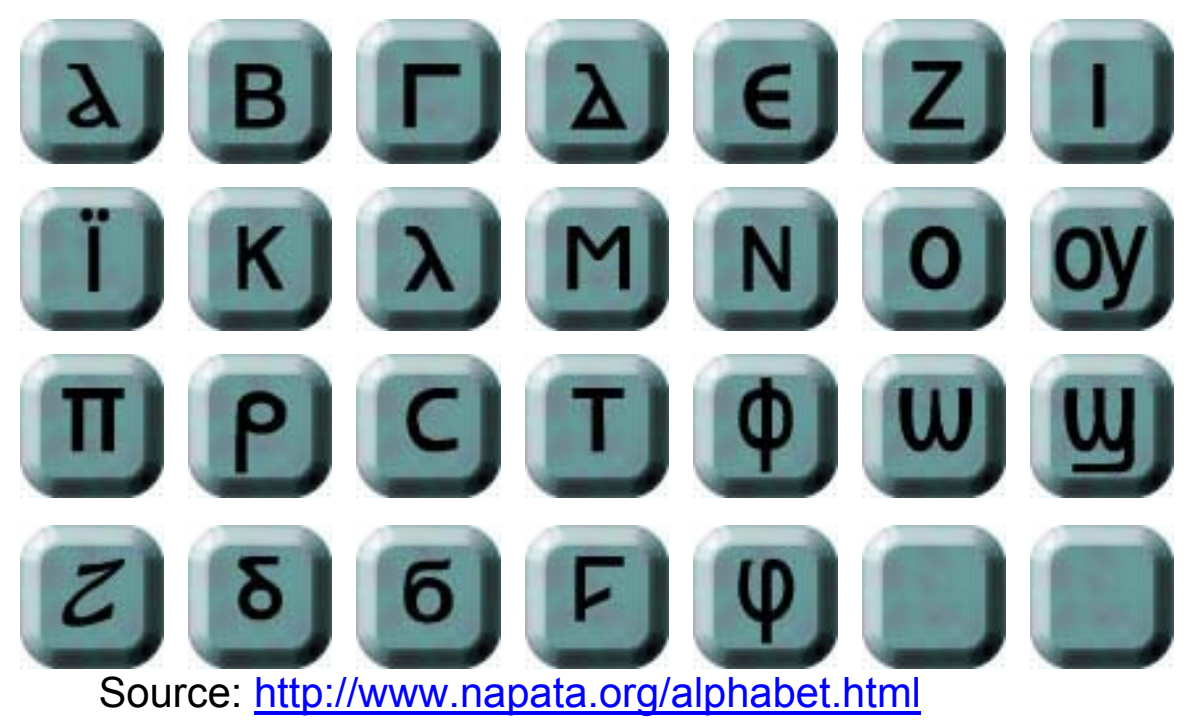

\subsection{Ethiopic syllabary}

The Ge'ez or Ethiopic syllabary ${ }^{6}$ is the only South Semitic script to have survived until today and it is used for a number of Semitic and Cushitic languages. In the first decades of the first century BCE southern Arabian immigrants brought the Sabean language to Ethiopia. Early in the next millennium, a distinctive Ethiopian version, influenced by the indigenous Cushitic peoples, was used in stone inscriptions (Hetzron 1997:242). Due to Greek influence the writing changed from left orientation to right orientation. Vowel indication started to appear in the $4^{\text {th }}$ century CE when the Aksumites converted to Christianity. Pankhurst (1968:25, cit. in Asher 1994:1149) suggests that the reason for the modification of the alphabet may have the "wish to make Biblical texts more intelligible to the newly literate." The Bible was translated into Ge'ez from Greek. Greek influence is also seen in the organization of the Ge'ez letters, which is similar to the organization of the Greek alphabet.

Apart from Amharic and the classical language Ge'ez, Tigre and Tigrinya are written in Ethiopian script until today (Haarmann 1990:328f). With regard to Tigre a striking fact is that it was graphized in Ge'ez script around 1880 by Catholic and Swedish evangelical missionaries (Woldemikael 2003). Since Ge'ez is the holy language of the Ethiopian Orthodox Church, Tigre Muslims prefer to read and write their language in the Arabic script (Anonymous 2002). Since precolonial times the Ethiopic syllabary was, besides the Arabic and Roman alphabets, also used to write the Cushitic language Oromo. The 'Galla ${ }^{7}$ Spelling Book' by Onesimus Nesib ${ }^{8}$ (1884) uses 250 characters. In an attempt to adapt the Ethiopic syllabary to the particular structures of Oromo, Shaykh Bakri Sapolo (cf. Hayward et al. 1981), an Oromo nobleman, clandestinely devised a new writing system in the 1950s. Despite its over 300 symbols and some other shortcoming it gained popularity in parts of eastern Oromia. But the colonial authorities discovered it fairly soon and suppressed it, so that it never came into general use (Oromia online).

In the 1970s the Oromo Liberation Front declared Oromo their official language and opted for an adapted form of the Latin script, i.e. Qubee (cf. 'Qubee on the web'). Its capacity to differentiate vowels made it more appropriate for Oromo than the Arabic script (Gamta 1992). Writing the Oromo language in any script was officially banned by the government of Haile Selassie (1941-1974). In 1974 the ban was lifted and there was liberty to write Oromo using the Ethiopic syllabary, but the use of the language for school education was interdicted. In May 1991, five months after the 
collapse of Mengistu's regime, Qubee became legally recognized. Within a few years the production of literature in Oromo was revolutionized, more books, newspapers, and magazines were produced in Oromo from 1991 to 1997 than from the 1880s to 1991. In 1997 all Oromo newspapers and magazines were closed down, and in March 2000 the use of Qubee in Oromia again banned. In the internet. Today it is medium of school education and an important language on the web (cf. Bilisummaa, online)

It is worth noting that other Cushitic language groups in Ethiopia, e.g. Hadiyya and Kambaata continue to debate which script to use, Roman or Ethiopic (Unesco 2004a).

\section{Sample text in Ge'ez}

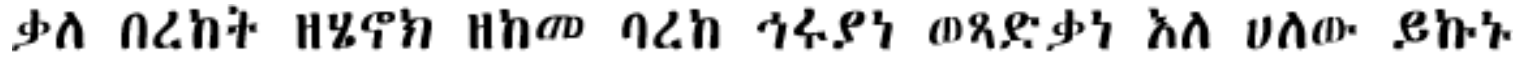

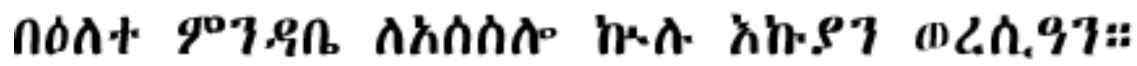

\section{Transliteration}

Kalä bäräkät zä-Henok zäkämä barräkä hgruyanä wäṣadkanä 'əlä häläw yəkunu bä‘alätä mandabe lä’äśäślo kwilu 'akuyan wäräśi'an

Source: http://www.omniglot.com/writing/ethiopic.htm

\subsection{Tifinagh alphabet}

The Berber alphabet is derived from the ancient Numidian script with some influence from the South Arabian and North Arabian scripts (Ager, online). The Berbers most certainly adapted the script to their own language when Numidian was still spoken. The earliest inscriptions for which the dates are known were made sometime during the 2nd century BCE, though the ancient Berber script may be six or seven hundred years older than that. The Berber script culture was rather unassuming, and it was replaced by Arabic during the expansion of the Arabs in North Africa during the $7^{\text {th }}$ century (Haarmann 1990:414). From the $12^{\text {th }}$ century onwards, Berber languages were written with the Arabic alphabet and there are also some Berber texts in the Hebrew alphabet written by Berber Jews (Ager, online).

The designation 'Tifinagh' literally means 'the Punic symbols'. It originates from the southernmost Berber groups, the Tuareg, who alone have preserved this script (Haarmann 1990:414). It is usually used by women for private notes, love letters and in decoration. For public purposes, the Arabic alphabet is normally used (Ager, online). Galand (2004) observes that it is remarkable for a script to have survived for such a long time when the language serves almost exclusively for oral communication.

Since the 1960s a revival movement for Berber culture and language can be observed in Morocco and Algeria. Among the targets are the official recognition of Berber as a national language and its development to become a modern means of communication. Furthermore all written and oral Berber literature should be documented (Kratochwil 2003:3). In Algeria Berber was declared national language on March 12, 2002. In Morocco the Institut Royal de la Culture Amazigh ${ }^{9}$ (IRCAM) was founded in 2001 to implement the use of Berber in school education. Since September 2003 children in Moroccan primary schools are taught to write Tamazight with the Tifinagh alphabet (Ager, online).

In October 2002 the majority of Berber associations opted for Latin script because of its modernity and compatibility, but in February 2003 Tifinagh was declared 
the official script of Berber in Morocco. The decisive argument was the script's authenticity (Kratochwil 2003:20).

There are currently many websites referring to the Tifinagh script, including articles on the language, history and culture. Most of these are written in French. French is also the first language of communication in the forums, e.g. on the site amazighweb.com. The use of Tifinagh is very much restricted to the discussions about this language. And even here, a considerable part of contributions is written in French.

\section{Sample text in Tamazight}

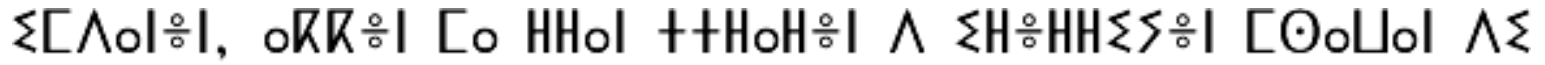

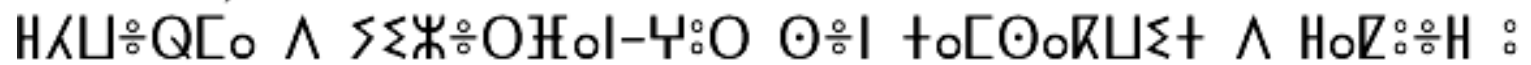

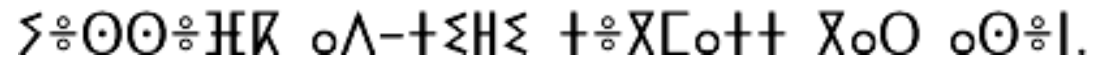

Source: http://www.omniglot.com/writing/tifinagh.htm

\subsection{Ajami}

About 1.000 years after the Arabs introduced their language and script in North Africa, peoples south of the Sahara began to write their languages in adapted forms of the Arabic script, Ajami. ${ }^{10}$ Since the $17^{\text {th }}$ century religious texts and poetry were published in Kiswahili, Hausa, Kanuri, Fulfulde, Wolof and Bambara. Furthermore historical studies are documented in Hausa (cf. Pilaszewicz 2001) and journals in Fulfulde $^{11}$ (Iro online). According to Prah (2004), even the earliest writings of Afrikaans were written in Arabic script.

Swahili literature in Arabic script was sufficiently important to motivate German colonial administrators, who had to learn Swahili, to also master Ajami (Bromber 2002). With regard to the introduction of the Latin script for Swahili, Hunwick (2005) states that "decoupling" of Swahili from the Arabic script may be regarded as a way of "de-islamising" the language. Romanization of Swahili was on the agenda of missionaries and later colonial officials and nationalist language-planners. The advantages of Roman script, however, may be fewer than what students of Swahili are usually told. As Frankl noted (1998:191-93, cit. in Hunwick 2005:27), there was "no particular reason to romanize Swahili; the language is no easier or more difficult to read in either script. The administration of German East Africa, throughout its duration, regarded Arab script (swah. Kiarabu) as normal, and made no effort to change it."

After Hausa was reduced to writing in Ajami early as the $17^{\text {th }}$ century, the number of publications increased in the following two centuries and the script was still in use in the first decades of the $20^{\text {th }}$ century (Philips 1996). In 1902, Lugard, conqueror and Commissioner of Northern Nigeria replaced Ajami the by Roman script, called Boko, against the advice of several specialists who favoured the former. Boko script should facilitate teaching Hausa to military and civil servants. The established Ajami-based literary industry constituted a considerable impediment for the educational policy of the colonial powers in predominantly Muslim areas, but in the end the script was to a great extent abandoned for the Roman script.

Despite the decline of Ajami for African languages, following the introduction of Roman script, it is still used throughout the Islamic Sahel for religious writings, archiveing and some other text genres. In Nigeria, the Borno Local Authority made efforts to develop an official Ajami orthography of Kanurim but the work was never 
completed (Kanuri Language Page). The initiative appears to have been so unimportant that it is not mentioned in Löhr (1997). Nevertheless, the Ethnologue (Gordon 2005) gives the "Ajami script" as the first entrance in the category "Language development" on the Kanuri-page. In Niger, ONEE (Organisation nigérienne pour l'éducation environnementale), a local NGO, uses Hausa textbooks in Ajami script in madrassas (qur'anic schools) successfully for health education. The idea to teach responsibility for health and the environment was initiated in 1993 by the IUCN (International Union for the Conservation of Nature (Thaly 2005). That Ajami is a living script for Hausa, becomes clear by the fact that $3 \%$ of the letters to the editor in Hausa-section of the Deutsche Welle are written in Ajami (Hannelore Vögele, p.c. Sept. 2006).

In Guinea, Fulani poetry was written in Ajami from the middle of the $18^{\text {th }}$ century, and the script is still in use. In Niagara, a formerly important village in the Mamou region it was discovered that accounting, written in Ajami, of all activities had been scrupulously kept. Their system was subsequently spread to the entire network of local village associations of the immediate region and finally, in 1992, to all administrative affairs and correspondence of the local development administration in Mamou. Newcomers in the area are taught the standardized UNESCO transcription for the Arabic writing of African languages in the Niagara Primary School after the normal class hours(Easton \& Peach 1997:22).

An important function of Ajami is that of uniting peoples with shared languages who are dispersed throughout the Sahel, in particular speakers of Fulfulde and Hausa. In 2005/2006 Ajami's importance increased when its study and the evaluation of literature written in Ajami were declared an integral part of an American research project "Diversity and Tolerance in the Islam of West Africa". The project is directed by the Harvard and Michigan State Universities, operating under the umbrella of the West African Research Association (AODL, online).

Fallou Ngom (2005) opts for the creation of schools using standardized Ajami scripts for Wolof, Berber, Pulaar, Mandinka, Hausa, Swahili, Zarma, Songhay and other languages as a step forward towards the linguistic unification of Africa. This could revitalize the common historical heritage as well as cultural and linguistic relationships that have existed between Muslim communities across Africa for centuries. This idea is in agreement with Prah's (1997, cit. in Prah 2004) claim that the literature in African languages written in Ajami is a central area for research on collaboration between Africans and Arabs. Ngom further claims that Ajami could also be used for a modern $21^{\text {st }}$ century curriculum for Qur'anic schools across Africa for the teaching of such subjects as science, mathematics, geography, and history. The example mentioned above of Qur'anic schools in Niger shows that Ngom's idea has already partly already materialized. 
Arabic alphabet for Hausa (ajami)

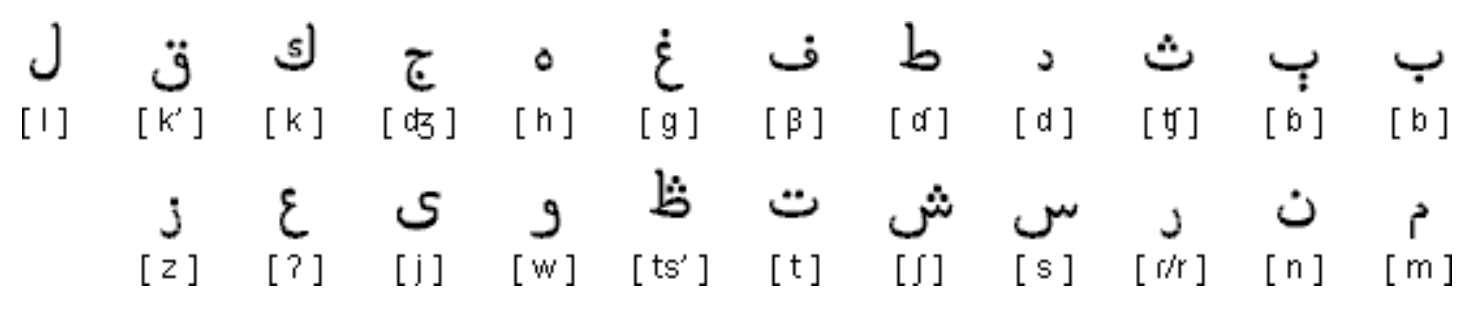

Source: http://www.omniglot.com/writing/hausa.htm

\section{Roman script}

By the turn of the $16^{\text {th }}$ century there were Portuguese missionaries in the Kingdom of Kongo and in Ethiopia, but their linguistic activities led to no more than the editions of a few religious books. The second introduction of the Roman or Latin script to the African continent began south of the Sahara by the end of the $18^{\text {th }}$ century and is still going on. From this time missionaries went to Africa with the clear intention of teaching the population groups to read and write in their own languages and develop a culture of literacy.

The foundation of Fourah Bay Institute ${ }^{12}$ by the Church Missionary Society (CMS) in $1827^{13}$ marks the beginning of intensive research on African languages and the search of a maximally unified alphabet with Roman letters. After the first attempts of a set of "Rules for reducing unwritten languages to alphabetical writing in Roman characters, with reference especially to the languages spoken in Africa" (Henry Venn 1848, cit. in Löhr 1997:82) were not generally accepted, the CMS organized in 1854 the first conference on African orthographies in London. The target was to create a "universal system for the description of orthography, particularly for previously unwritten languages (Spencer 1966:96, cit. in Löhr 1997:82). The struggle for unified alphabets on an international level was to continue for more than a century and with regard to a number of languages is not yet solved.

Religious education was not always welcome by the populations groups converned and graphization programs sometimes were even less. A case of particularly strong rejection was observed in Darfur. Until recently, the speakers of the Fur languages opposed to have their language reduced to writing and opted for a diglossic solution: written communication should be carried out in Arabic and Fur should be restricted to oral communication. Speakers of Fur even refused to cooperate with linguists who came for short visits to collect data and leave. The rejection was effective enough to impede a comprehensive description of Fur. Only speakers or Arabicized varieties of Fur were ready to give the information wanted. This is why there is not yet a Fur reader available. The political development in Sudan made many speakers of Fur change their views concerning the communicative roles of Arabic and local languages. They have begun to foster their language and make efforts to ensure that their children no longer learn Arabic as the first language, but Fur. They even have developed an interest in having their languages written and for this aim happily cooperate with linguists from abroad. (Christine Waag, p.c.).

Most linguistic groups were less opposed and even happy to have their language graphized and be taught to read and write. Some missionaries were highly admired for their job by the groups concerned and have kept a long lasting good memory. Outstanding examples are Westermann for Ewe (Pasch 2005) and Hulstaert for Mongo (Vinck 1996). 
Despite all efforts of missionaries to alphabetize the peoples of Africa and the interest of the population in alphabetization the majority of African languages have by and large remained oral media which hardly serve for written communication. Among the exceptions are Swahili, Zulu, Hausa, Amharic and Somali. With the exception of the Arabic countries in North Africa, the former colonial languages still constitute the media for by far the major part of written communication and print production in all African countries.

\subsection{History of standardization}

The graphization of African languages and the creation of standardized orthographies in Roman script ${ }^{14}$ as a prerequisite for a culture of literacy by Christian missionaries of various congregations constitutes the earliest language planning activities in Africa (cf. Haacke 2005:157). Many of the missionaries were well trained linguists, e.g. Christaller, responsible for the orthographies of Fante, Asante and Akuapem, Westermann, responsible for the orthography of Ewe, and Moffat for the orthography of Tswana (Simmons 2000). They were successful insofar as today most African languages with a writing system use adapted forms of the Roman script.

Aiming at unified orthographical systems they had to cooperate with each other and also with the colonial administrations at an international level. Orthographical questions were discussed on international conferences on education three which convened in Uganda (1918), in the Belgian Congo (1924) and in Rejaf/Sudan (1928). On the latter conference it was decided that Bari, Dinka, Lotuxo, Nuer, Shilluk and Zande would collectively suffice for the educational needs of southern Sudanese peoples, and orthographic guidelines were developed as the standard reference for all later orthographic development of Southern Sudanese languages. The last big conferences dealing with the problem of unified orthographies on national and international levels took place in Bamako 1966 (Bisharat). At present international conferences dealing with problems related to the production of literacy and knowledge in Africa, discuss rather the design of fonts for the production of digital texts than problems of orthographies.

Not always would missionaries and colonial administrations cooperate with each other. The missionaries' targets were other than those of the colonial administrations. They aimed at diffusing Christian religion and for this aim they produced religious, edifying and instructive literature and taught the population to read and write. Dewees (1977:129) states that more languages have been graphized for Christian missionary purposes than for any other aim.

The different interests of the two groups caused problems and many missionaries suffered from obstruction by the Colonists. Allowance to enter the desired area of work was to adjourned sine die or for good, and permissions granted at a given moment may have been cancelled at another. This is described in detail with regard to the history of the Grace Brethren Mission in Central Africa (Anonymous, online). A statement in the Koloniale Zeitschrift (cf. Schaff ch. 4.4.) shows clearly that colonialists perceived the alphabetization efforts of the missionaries as counterproductive to their own work: "We have acquired this colony not for the evangelization of the Blacks, not primarily for their well-being, but for us Whites." Although it is true that missionaries sharing nationality, language and religion with the colonial administration had less difficulties than others, the links between the Catholic missionaries in French Equatorial Africa and Belgian Congo were less close than Samarin (1989a:162) claims. But they did have better conditions than the English, American and Swedish evangelical missionaries in these colonies. A rule which all missionaries in the British colonies had to follow was that the literature in African languages which 
they produced should only deal with religious or trivial topics, or be pragmatic. Any ambitious and/or critical piece of literature had to be written in English and published abroad (Veit-Wild 1984:104).

In order to reduce a certain language to writing the early missionaries quite usually chose the variety spoken around their mission station as a basis for the written standard form to be created. In some areas lingua francas, e.g. Kikongo, Kiswahili, Sango were the preferred choice. A third solution was the artificial creation of a common standard of a dialect cluster, which is not based on any specific local dialect. Shona, Kalenjin and Luhyia are the best know examples. The production and dissemination of texts in the chosen varieties increased their prestige among speakers of other varieties. Union-Igbo, proposed in 1905, an artificial variety that should be intelligible for speakers of all lgbo dialects, became the literary variety of Igbo. Bishop Oluwole compared the standardizing effect of the missionary-created variety on written Igbo with Luther's translation of the Bible on standard German: "What Luther's Bible has done for Germany, this Union Ibo version would do to enrich the language and unite the peoples in the Ibo-speaking region of Southern Nigeria." (cit. in Ludwig 1991:188)

A major result of the missionaries' linguistic activities was an enormous increase of knowledge on African languages (Johnston 1906:252). But they were less successful in providing a widespread high level of literacy all over the continent and in laying the foundations for a flourishing print industry.

\subsection{Reactions to the standard orthographies}

The orthographies for quite a number of languages were accepted from the very beginning and have been used quite successfully until today without significant modifications. This is particularly true for the languages soon became media in commercial print publications, e.g., Zulu, Xhosa, Swahili, Luganda and Yoruba. ${ }^{15}$ In many other languages the early orthographies are hardly used for written communication other than reading the Bible and prayer books.

As I could observe in several schools around Pretoria (South Africa) many pupils declare "mother tongue", i.e. instruction in and of the new official languages, the most difficult subject. The pupils' difficulties result from a widespread incompetence in the standard versions of these languages, standard version representing rural varieties from about a century ago and quite unlike the varieties currently spoken in the urban areas. Nevertheless, they are not questioned by the populations concerned, and innovations are not easily accepted. This leads to a dilemma in teaching to read and write the respective languages. Texts in the varieties actually spoken do not exist. If they were available, they would not necessarily be a good solution, since pupils and teachers consider these current varieties as faulty and not worthy to be written.

These observations remind of an experience by S.I.L. missionaries with regard to Congo-Swahili which is well known among Africanists. This variety differs so much from East African standard Swahili that the latter is not understood, hence it constitutes an 'Abstandsprache' (Kloss 1967). To improve the situation the Bible and prayer books were replaced by new ones written in the local variety. The reaction of the believers was, however, a rejection of religious texts written in an "incorrect" language, and they insisted on having books written in the "correct" East African standard variety of Swahili. Fishman (1988:280) explains such behaviour as follows: "Replacement of a writing system threatens to dislocate indigenous intellectual authority structures. The longer the prior writing system has functioned as an indigenous marker of authenticity and status [...] the less likely it is that this established system will be completely replaceable without extreme dislocation." 
New orthographies may be appreciated by the speakers (cf. Sango, ch. 5.6.). But there is the risk that neither the old nor the new systems are mastered. After two modifications of Bambara orthography in 1978 and in 1993, e.g., Dumestre speaks of an 'orthographical anarchy' (Skattum 2000:108). For the mastery of any orthography it is absolutely necessary that the speakers get continuously orthographically correct input from books, journals and newspapers, but also from flyers, noticeboards, information panels and inscriptions of all kinds, which make up a linguistic landscape. ${ }^{16}$ Cases of evidence are the European orthographies. They have at all times changed gradually, with only very few official updatings taking place as in French, Spanish and German, or none as in English. ${ }^{17}$

\subsection{New African scripts}

With regard to some languages, such as Bambara and Sango, linguists considered the orthographies provided inappropriate and they revised them. For other languages which were given none or unsatisfactory orthographies new scripts were created by individual speakers. A major aim was the empowerment of the linguistic groups so that they could compete with the societies that apparently were more advanced because of their literacy. The majority of the new scripts are syllabaries, but there are also two alphabets. Most of the autochthonous scripts were designed in Liberia/ Sierra Leone/ Guinea/ Senegal, two in Cameroon, one originates in Somalia and the most recent script was designed in the DR Congo. The concentration in West Africa is striking. It may be a secondary effect of the alphabetization work of the Fourah Bay College which was felt even beyond the borders of its direct influence. Here linguistic groups may have felt disadvantaged because they were not given an orthography like their neighbors. Liberia's very special case of colonization provides another explanation In 1822 the United States of America set up the country as a homeland for freed slaves from the United States. So the peoples of Liberia came into contact with English-speaking people from America, who had some knowledge about writing.

The authors of all new scripts had met a foreign person who owned the "talking paper". They not only had admiration for this powerful tool of communication, but they adopted it and created a writing system for their own language (Schmitt 1963:14). The actual inspiration, however, was given in a dream, where they were given the task to create a script and also some conceptual ideas on what it should look like.

Many of the modern African scripts suffered at the hands of colonial officials who did not support their usage or to repressed them (Tuchscherer 1999:157). None of the new scripts had a chance to win recognition as a general medium of writing against the Roman script. Most of these scripts have diminished over time, and when in 1986 an exhibition was organized to demonstrate the genius behind the different African writing systems (Dalby 1986), they were already treated as museal objects reminding of a more glorious past. Despite the omnipresent Roman script, which for socio-economic reasons is in the stronger position, most local scripts currently experience a revival, resulting from local initiatives but also supported by missions, NGOs and - very important - from diaspora communities. It is not astonishing that online information on the new autochthonous scripts is rich, offering a more comprehensive overview than print sources. The African scripts apparently constitute marketable objects, and for almost all of them fonts are available or under production. This explains why, apart from academic institutions, it is commercial font designers who edit the respective websites (Ager, online; SIL, online; Bekerie 1996, ziva 2000, Glavy 2003). 


\subsubsection{Vai syllabary}

The Vai-script is the oldest autochthonous African script of modern times, "independent [of Latin and Arabic script], original, syllabic and phonetic" (Koelle 1854:229). Following the inspiration of a dream to create a writing system for his language, Dualu Bukele of Jondu designed it in the 1820s, assisted by his friends. The king's support was of great help. He himself had a political interest in raising "his people on a level with the Poros ['Europeans'] and the Mandengas, who hitherto had been the only book-people" (Koelle 1854:235ff). The script became popular among the Vai and by the end of the $19^{\text {th }}$ century most of them were using it (Ager, online). Its use did not stop in the $20^{\text {th }}$ century, and in 1962, the Standardization Committee at the University of Liberia standardized the syllabary.

It was discovered in 1848 or 1849 by F.E. Forbes (1957), an American officer, who, in cooperation with Edmund Norris, made a first publication on it. Delafosse (1899:294) considered the script a unique development in modern Africa and was convinced that no other ethnic group in Africa would possess a comparable script, i.e. one apt to put to paper any idea in Vai and also in other languages. ${ }^{18} \mathrm{H} . \mathrm{H}$. Johnston (1906, cit. in Tuchscherer 1999:58f), however, called the Vai script characters "clumsy adaptations of Roman letters or of conventional signs employed by Europeans", adding that the Vai syllabary had "little logic", and he even called on the Liberian government of the period to "combat this movement".

Because the script is so important to the Vai people, the LBTC (Lutheran Bible Translators of Canada, online) decided that the New Testament should be printed using the Vai script. For this aim they cooperated with SIL and script experts from the Vai community in developing the SIL Vai Fonts (1999) ${ }^{19}$. "For the first time, the characters of the Vai script could be keyboarded into the computer and printed on laser printers. Literacy materials soon appeared, followed by health booklets and Scripture portions." (LBTC, online) In April 2005 a meeting took place at the New York University where the development of Unicode characters for Vai was discussed, which allow the production of digital texts (cf. Everson et al. 2005).

Today the Vai use in three different languages and scripts: the Vai syllabary is used in casual social communication among community members, while in Arabic is read aloud as part of Moslem religious practice. English is used predominantly for formal, governmental pronouncements and documents. In a comparative study of textbooks and teaching methods Sylvie Scribner (1981) found that Vai children become significantly better literate in Vai script than in English and Arabic.

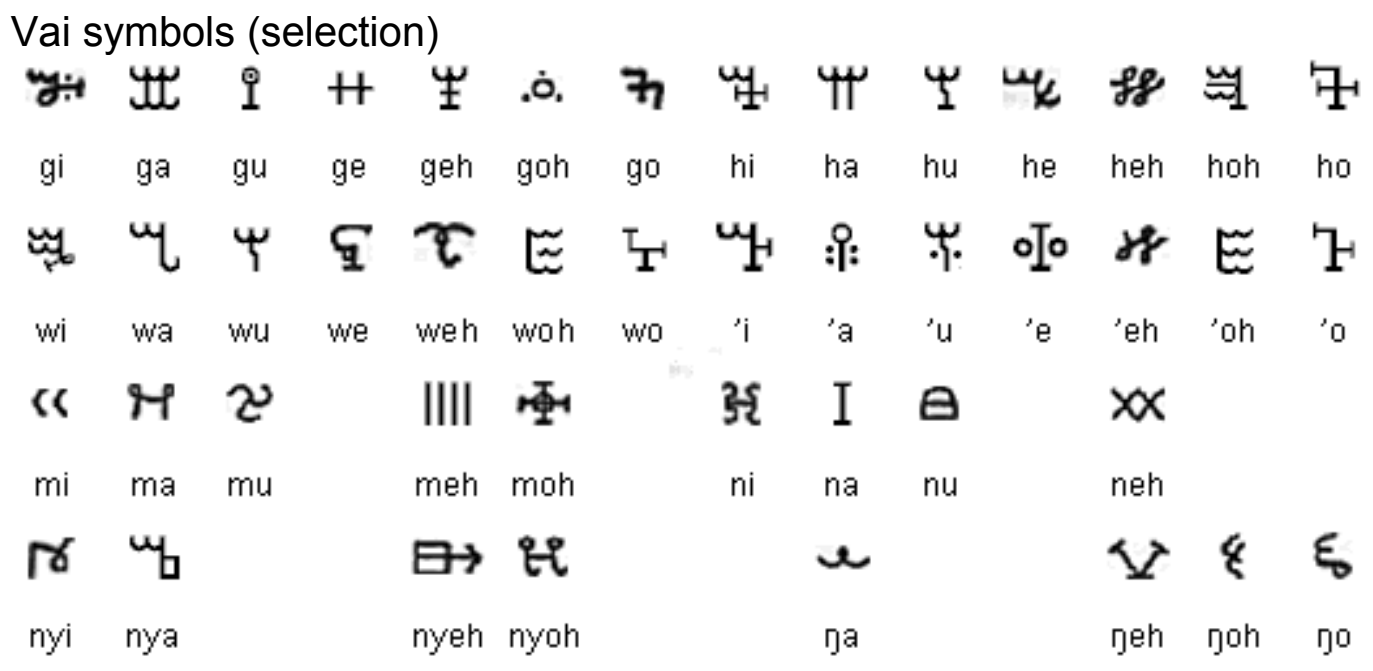

http://www.omniglot.com/writing/vai.htm 


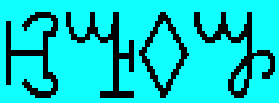

Source: $\underline{\text { http://www.geocities.com/jglavy/african.html }}$

\subsubsection{Bassa alphabet}

In the late 1800s, Flo Darvin Lewis, speaker of Bassa, went to America in order to study medicine. When he returned to Liberia in 1910, he brought a Bassa alphabet he had developed. Unlike Vai it is an alphabet, not a syllabary, the new version of which can be used on a standard computer keyboard. The Bassa Vah Association ${ }^{20}$ strives to expand the use of the Bassa script for the printing of newspapers, literature, science and religious texts. They offer Bassa fonts which allow to use the language in digital texts (Bassa Vah Association, online). 


\section{Bassa alphabet}

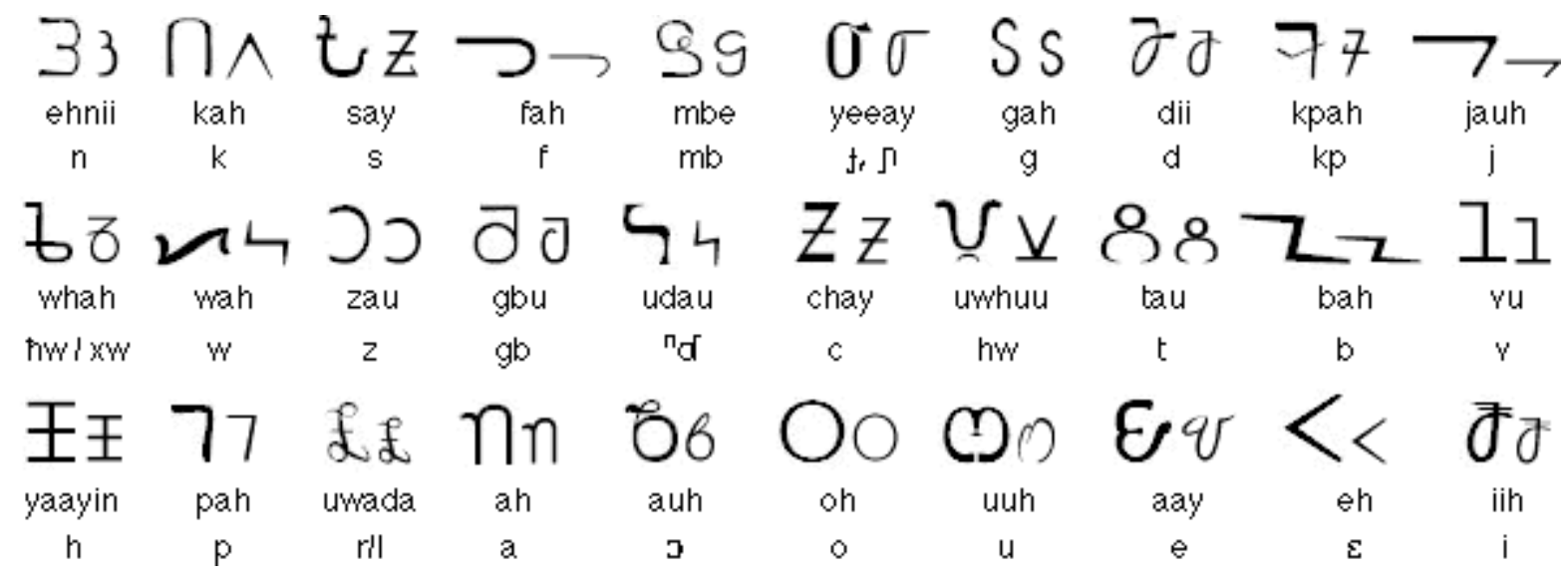

Source: http://www.omniglot.com/writing/bassa.htm

\subsubsection{Mende syllabary}

The Mende script, a syllabary, was created in 1921 by Kisimi Kamala from Sierra Leone. Inspired by a dream he thought that the power of the English resulted primarily from their literacy. In order to provide his people with the same power he designed a script, which he named Ki-ka-ku. It contains 195 symbols and is written from right to left. After the British gave order in the 1940s to alphabetize the Mende in Roman script the Mende script became obsolete. (Ager, online)

Mende symbols (selection)

other combinations

\begin{tabular}{|c|c|c|c|c|c|c|}
\hline$\partial^{\circ} \alpha_{0}$ & 맘 놀 & ! & Lto & 顿 & 害 & $\Leftrightarrow$ \\
\hline$w \varepsilon \mathrm{i}$ & $g \varepsilon \mathrm{i}$ & $\varepsilon \mathrm{i}$ & Igua & gua & kua & hua \\
\hline$R \rho_{3}$ & $\Leftrightarrow$ & 番乐 & 宁 भI & $\curvearrowright \mathrm{J}$ & 6otg geo & $l 6$ \\
\hline mua & nua & fă & $\mid \varepsilon \varepsilon$ & hel & hou & mũc \\
\hline
\end{tabular}

Source: http://www.omniglot.com/writing/mende.htm

\subsubsection{Kpelle syllabary}

The Kpelle syllabary was invented during the 1930s by Chief Gbili of Sanoyea, Liberia. It was used to some extent by speakers of Kpelle in Liberia and Guinea during the 1930s and early 1940s but never achieved popular acceptance (Ager, online). 


\begin{tabular}{|c|c|c|c|c|c|c|c|c|}
\hline & $i$ & a & $\mathrm{u}$ & $\mathrm{e}$ & $\varepsilon$ & 0 & 0 & - \\
\hline $\mathrm{p} / \mathrm{b}$ & Y. I. It: & 拜 & \# & $\mathscr{W}$ & 6 & $Y$ & pe pe & \\
\hline b/mì & $\Psi$ & 망 $\delta_{\text {w }}^{c}$ & & $\psi X$ & e & & $\gamma_{0} x_{\text {wes }}$ & \\
\hline $\mathrm{kp} / \mathrm{gb}$ & S & $\div \%$ & $x$ & if & $\mathcal{C}_{P} \mathrm{C}_{3}$ & qe e & - $-1 / \mu \mid \mathbb{E}$ & \\
\hline$f N$ & ys 7 & $N z$ & & & $\Varangle$ & $\phi g$ & $p p$ & \\
\hline$t / d$ & $2 x X_{(\mathrm{di})}$ & $\eta \mathscr{H}$ & $\left.\mid g^{2}\right)^{\prime}$ & $p r$ & $\sim$ & 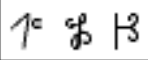 & $\beta^{3}$ & \\
\hline $1 / n+n$ & F. x & $t_{2}$ & \& & Le" & 4. Dow & $\gamma \phi$ & FF & \\
\hline$h(s) j(z)$ & $\delta \varkappa$ & $\varkappa^{\prime \prime} z$ & $p$ & $y^{\prime}$ 唯 & ঠ" $\boxplus$ & $Y_{11}^{\prime \prime}$ 야 & $r r_{c}$ & \\
\hline$y /$ iny & $g^{\prime} \quad \alpha$ & $\gamma \omega$ & & $4 k$ & 40 & & & $\gamma \| 0$ \\
\hline $\mathrm{k} / \mathrm{g}$ & cher & 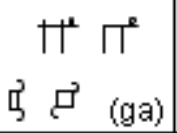 & 为 & $j=g$ & CV wy beu & $\pi$ & \% मू' & \\
\hline $\mathrm{kw} / \mathrm{gw}$ & $e_{\gamma}$ & & & $c \gamma \alpha \phi^{\gamma}$ & $\beta \sim$ & & & \\
\hline$\gamma(/ j)$ & $d^{\omega}$ dz̨ & c|⿲丿丨 & & & 4.2 & & & \\
\hline$\gamma / w$ & & & fel & & & 为 & $\odot$ & \\
\hline$w(/ j w)$ & $\gamma c$ & $\begin{array}{l}\text { HHP } 0 \| 0 \\
M_{\text {(war) }}\end{array}$ & $\begin{array}{cc}{\left[\begin{array}{cc}f & 0 \\
\text { (wun) }\end{array}\right.} \\
\end{array}$ & & $\because 89$ & $\begin{array}{c}\mathscr{n} \\
(\text { wan })\end{array}$ & & \\
\hline- & & & & & $2+d m$ & & & \\
\hline $\begin{array}{c}\text { nasal } \\
\text { syllabes }\end{array}$ & $\tilde{i}$ & ã & แี & ẽ & $\tilde{\varepsilon}$ & 5 & - & $\begin{array}{c}\text { syllabic } \\
\text { nasal }\end{array}$ \\
\hline $\mathrm{m}$ & $\infty \infty$ & $\varphi \varphi$ & to por & & & 88 & & \\
\hline$n$ & Her 1180 & $B B$ & $8+9$ & $\Psi 2$ & & & & \\
\hline ny & & 1218 & & $\beta^{\prime \prime \prime} *$ & B & abs 8 & & \\
\hline ワ & & $d_{i} /$ & & & & & & we $\mathrm{m}$ \\
\hline
\end{tabular}

Source: $\underline{\text { http://www.omniglot.com/writing/kpelle.htm }}$

\subsubsection{Loma syllabary}

The Loma syllabary was designed during the 1930s by Wido Zobo of Boneketa, Liberia. It consists of 185 symbols and is written from left to right in horizontal lines. It was used among the Loma people, mainly for personal correspondence, during the 1930s and 1940s, but then was replaced by Latin script and now is no longer used. (Glavy, online). 


\begin{tabular}{|c|c|c|c|c|c|c|c|}
\hline & $i$ & a & $\mathrm{u}$ & $\mathrm{e}$ & $\varepsilon$ & 0 & 0 \\
\hline $\mathrm{p}$ & W & FI & $\mathrm{H}$ 画 & + & Ш & $P^{H} P^{r} \otimes$ & $\Perp \overline{\overline{\|}}$ \\
\hline$w$ & 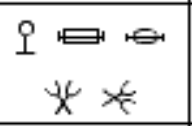 & $\begin{array}{c}\mathrm{m} M \\
\mathrm{~m}\end{array}$ & & कृ मे & )$x$ & re & 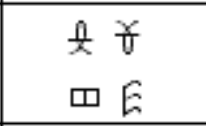 \\
\hline$b$ & $\infty \infty$ & $\infty$ & $P b \theta$ & $x$ & ૫ज ह & $\mathrm{WM}$ WW $\mathrm{W}$ & $\begin{array}{c}\sigma-\gamma \\
\gamma \alpha\end{array}$ \\
\hline b & $N)($ & $\Psi$ & $\Phi$ & لإ & r্d\|r্d & $|\gamma|$ & 艙 8 \\
\hline $\mathrm{kp}$ & & & & $\nsim f$ & & & \\
\hline$g b$ & WN & $\mathcal{H}$ & & IS & $c-$ & C. CC $\Omega$ & 양 \\
\hline ' & $\Psi$ & $R$ & & & & & \\
\hline$f$ & $\theta$ & $0^{*} \quad \dot{0} 0$ & $M M \mathbb{I}$ & $\|=\|=111$ & & ㅇ. & $G C$ \\
\hline v & $\leftrightarrow$ & $\Leftrightarrow \infty$ & 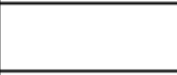 & i) $) \leqslant(1$ & $\odot \odot \ominus m$ & 平 & $B \& \mathbb{I I} \infty$ \\
\hline$t$ & * & \# & ※x $x$ & 米 & $\mathrm{w} U$ & i. & 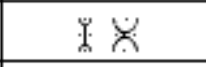 \\
\hline 1 & $w$ & $\odot$ & $\mathrm{KC}$ & $\delta$ & $\forall$ & $\mathbb{N} \mathbb{N}$ & $\gamma$ \\
\hline$d$ & $\Phi$ & $\odot$ & $\mathrm{ICCC}$ & + . & & Ш & 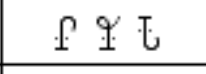 \\
\hline$s$ & $\& \& \&$ & $\mathrm{P}$ & 20 & $8 \%$ & 淡溇 & $\odot I$ & 35 \\
\hline$z$ & $\ltimes 凶$ & n & $\square$ & $Q W N$ & 4 & |م-2\| न्थ & $\overline{1}\left[\mathrm{~b}_{2}\right.$ \\
\hline$y$ & 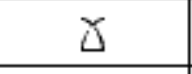 & $T$ & $m w j^{2}$ & $\oplus$ & $\partial^{x} \partial$ & $\stackrel{M}{\vdots}$ & $\therefore$ \\
\hline $\mathrm{k}$ & $\pi \underline{\|}$ & $V \gamma$ & $\mathrm{HH}$ & $8 \infty \theta$ & $\mapsto \mapsto \mapsto$ & ọ. I미 & 忩出 \\
\hline$x$ & 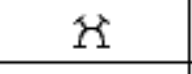 & 3 & & $\circ+\infty t$ & & & \\
\hline $\mathrm{g}$ & حبّ كִ & น & $k$ & $\div$ & 因射 & $\ominus$ & \\
\hline$n g$ & & 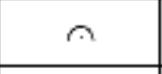 & & & & & $i \propto$ \\
\hline- & $\mathbb{1}$ & $\uparrow$ & $\mathscr{N}$ \ $N$ & $\Phi$ & G & G & $g o$ \\
\hline
\end{tabular}

Source: http://www.omniglot.com/writing/loma.htm

\subsubsection{N'ko alphabet}

The more recent modern African script is N'ko: It was created in 1949 by Sulemana Kante (Guinea) and is used mainly for Manding languages. It is written from right to left and has 45 letters to transcribe as many as 8,520 syllables. There are seven vowels, one neutral and nineteen consonants and diacritics to mark nasalization as well as length and quality of vowels. The script is most popular in Guinea and Côte d'Ivoire, with smaller user communities in southern Mali.

Kante created N'ko out of anger about foreigners who consider Africans as devoid of culture because they do not have writing systems of their own. He wrote hundreds of Malinke readers in N'ko, and textbooks on subjects as diverse as astrology, economics, history and religion. N'ko shall enable the Africans to document their history and culture in their mother tongues. (Ager, online)

UNESCO's Programme Initiative B@bel supported the preparation of a proposal to encode N'Ko in Unicode, and in 2004 the proposal was approved for ballotting by the ISO working group WG2 (UNESCO 2004b). 


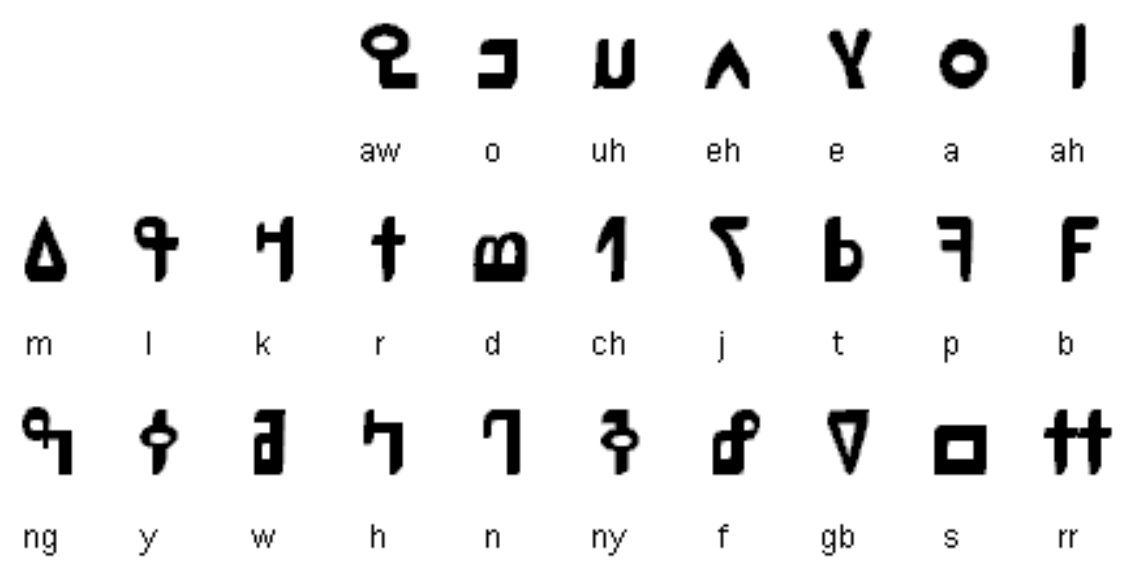

Source: http://www.omniglot.com/writing/nko.htm

\subsubsection{Bamum syllabary and Shumum language}

The Bamum-syllabary, also called A-ka-u-ku script, was discovered by Martin Göhring, member of the Basel-Mission, who published two articles in Der Evangelische Heidenbote ${ }^{21}$ in 1907. In 1963 Alfred Schmitt published his three-volume magnum opus Die Bamum-Schrift, in which he also discussed Cameroon's other script, Bagam. He made lengthy conjectures on possible connections between the Bamum and Bagam scripts, but admitted that little was known about the Bagam script and its characters were completely unknown. (Tuchscherer 1999:58)

It is not clear when exactly Sultan Ibraham Njoya, king of the Bamum, created this alphabet. According to Mafundikwa (2000) he did so around $1896 .{ }^{22}$ Inspired by a dream he asked his subjects to draw different objects and to name them. On the basis of their results, he created a secret court language, Shumum, and also the first independent writing system for the Bamum vernacular with some 466 pictographic and ideographic symbols. More cautiously and in agreement with Delafosse (1899), Schmitt (1963:14f) scheduled the beginning of the script between 1900 and 1905. Given that the first Whites came to Fumban on July $6^{\text {th }} 1902$, he assumed that the first design of the script took place in 1903. Six modifications followed between 1906 and 1916 (Schmitt 1963:107).

Njoya's aim was to resist the domination of colonial cultures, but Battestini (2004) claims that the "value allotted to this script and books cannot rely on their use but evidently on their function as a major source of pride and, thus, an important component of the Bamum identity." Njoya's love for this alphabet soon grew as he created 40 schools in his territory, in which only the script and Shumum, was taught. The glory was, however, short-lived. After the First World War, Njoya's schools and achievements were destroyed by the French colonial authorities and he was deposed in 1931 and exiled to Yaounde where he died as a humiliated and broken man two years later (Kuhl, online). The script was, however not forgotten. Tuchscherer (cit. in SEI, online) claims that the script is "still being taught; many extant texts; community interest high". There are even good conditions for a revival. Fonts for digital publications have been produced by Transcultural Design-Creative Solutions ${ }^{23}$ but Bamum is not yet on the list of languages for which a proposal for the design of a UNICODE font has been approved (SEI, online).

With a total of some 7.000 documents, the Bamum manuscript repository is under the threat of dieing. It is in the light of preserving such legacies that the US 
ambassador to Cameroon launched the Bamum scripts and Archives Preservation Project, which will be directed by Konrad Tutscherer (Tandafor 2006).

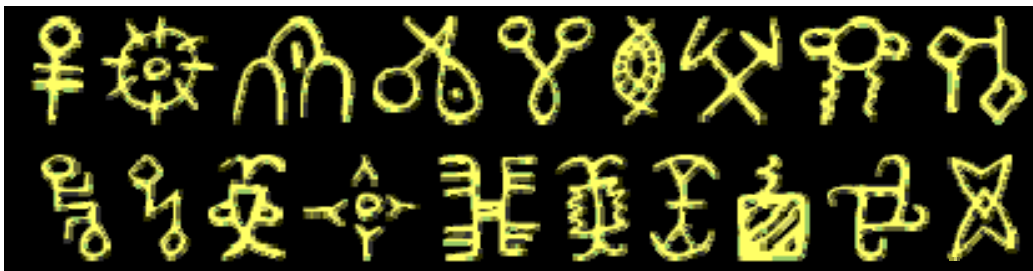

Source: http://www.members.aon.at/africanfonts.at/bamum.htm

\subsubsection{Bagam syllabary}

In 1917 L.W.G. Malcolm (1920-1921:127-9), Royal Artillery officer discovered that the Eghap employed a syllabic script to write their language in their principal town, Bagam. He was told that the script of the neighbouring Bamum was used as the basis for the script used in Bagam, and when the Bagam script broke down, characters were borrowed from the Bamum script. The Bagam chief pointed out to Malcolm that the two scripts were not the same, and Malcolm added that "this can easily be seen when comparing them".

The characters were reputed to total several hundred in number. According to Tuchscherer (1999:63) the basic unit of the characters, which Malcolm called syllabograms, appears to be the CV syllable, and signs also exist for independent syllabic vowels.

Today not a single document exists in Cameroon in the Bagam script, the alphabet having disappeared without a trace. The only known example of the Bagam script is held in the Haddon Library of the Cambridge University (British Library, online).

\subsubsection{Somali}

In 1920-1922 Cismaan Yuusuf Keenadiid designed a script particularly for Somali, called far Soomaali "Somali writing" or Cismaanya. It was ment to represent the Somali language (Emerson, online). When in the 1950s the Trust Territory of Somalia was consulted about the future of the Somali language, they overwhelmingly chose Arabic. The inadequacy of the Arabic vowel letters for writing down Somali caused considerable difficulties for the early orthographers, and the Arabic script could not completely replace Cismaanya.

Between 1961 and 1969, both Osmanya and a Roman-based script were used. The current Roman-based alphabet was officially adopted in 1972, and Osmanya fell into disuse. Today the Osmanya script is only used symbolically by the SYL (Somali Youth Movement) (Mohamed Adan Ibrahim, online). 


\section{Somali/ Osmanya alphabet}

\begin{tabular}{|c|c|c|c|c|c|c|c|c|c|c|c|c|c|c|}
\hline$\gamma$ & $y$ & of & 1 & $M$ & fo & 0 & 7 & 8 & $q$ & $\mathrm{t}$ & $y$ & $r$ & 4 & $\mathcal{H}$ \\
\hline 64 & ys & 2.5 & is & rs & fos & own & 75 & 35 & 2402 & is & 4582 & RS & 4.5 & KG \\
\hline lef & ba & ta & ja & $x a$ & kha & deel & ra & sa & shiin & dha & cayn & ga & fa & aaf \\
\hline & $b$ & t & j & $x$ & $\mathrm{kh}$ & d & $r$ & 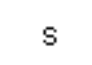 & sh & $d h$ & c & g & $f$ & \\
\hline [?] & {$[b]$} & {$[t]$} & [ d b ] & {$[\hbar]$} & {$[x]$} & {$[d]$} & {$[r]$} & [s] & {$\left[\int\right]$} & [a] & {$[s]$} & [g] & {$[f]$} & [q] \\
\hline y & $\Omega$ & $b$ & 2 & to & 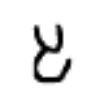 & 8 & $S$ & $U$ & 9 & 3 & $\lambda$ & 9 & $\omega$ & $h$ \\
\hline$\forall G 4$ & ¿৭८ & btud & $2 \hbar 2$ & tos th & ES & 85 & 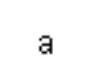 & e & $\mathrm{i}$ & 0 & u & aa & ee & Do \\
\hline & laan & miin & nuun & waw & ha & ya & [a] & [e] & [i] & {$[0]$} & {$[u]$} & [a: ] & [e: ] & [ $0:$ ] \\
\hline & I & 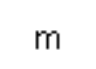 & $n$ & $w$ & 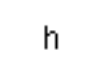 & & & & & & & & & \\
\hline
\end{tabular}

Source: http://www.omniglot.com/writing/somali.htm

\subsubsection{Wolof alphabet}

Wolof was written in both Roman and Arabic script (Wolofal), before in the 1960s a systematic romanized orthography was introduced. At about the same time, in 1960, Asane Faye, president of the African Languages Teachers Movement created the Wolof alphabet. The influence from Wolofal is apparent in the writing direction from right to left and in the disctinction of initial and non-initial forms of the 25 characters. A teaching manual of this script was published in 1966. The Roman alphabet was the bases for the official orthography, declared in 1974. (Coulmas 1991)

No image available.

\subsubsection{Mandombe syllabary}

Mandombe is the youngest autochthonous African script. Wabeladio Payi created it in 1978, inspired by dreams in which Simon Kimbangu asked him to carry out a mission for the black people. Mandombe is used mainly by the Kimbanguist church and taught in primary and secondary schools in the DR Congo, Rep. of Congo and Angola. It allows to write Kikongo, Lingala, Ciluba and Swahili, most tone languages and European languages such as French. The Centre de l'Écriture NégroAfricaine in Kinshasa is the academic base of Mandombe (fr.wikipedia, online).

Mandombe has not been encoded in Unicode and no proposals have been made hitherto to prepare it for online communication.

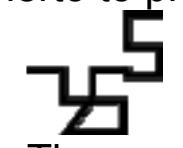

The word 'Mandombe' in Mandombe script.

Source: http://en.wikipedia.org/wiki/Mandombe

\section{African languages in the internet}

With the creation of internet technology a new medium for written communication has become available, which for a number of reasons is highly attractive with regard to the use of African languages. Therefore it is not astonishing that efforts are made in order to adapt African languages to the internet and teach the population computer 
literacy, which are comparable to those made at the turn of the $20^{\text {th }}$ century in order to spread the use of the Latin alphabet. The potential of the internet is recognized by basically all African governments and by national and international institutions dealing with communication, education and development.

Compared with the production of print media the production of websites is relatively cheap, easy and quick. Were costs the decisive factor, one might expect that online texts in African languages abound. But despite some highly ambitious institutional and private online-initiatives to promote certain languages, e.g., for Swahili (Kamusi-Project), Hausa (Hausa Home Page, K'ofar Hausa), Sango (Yângâ tî Sahngo tî Bêafrîka) and Somali (somalinet), online publications in African languages do not abound yet. It cannot be denied, however, that the online presence of African languages is increasing. It appears quite obvious that the use of African languages in the Internet reflects their use in print media to a high degree. Languages with a rich and marketable print literature also have a big number of online texts, above all comprehensive journalistic information. Among those are Somali, Oromo, Amharic, Hausa, Swahili and Zulu. Languages for which there is no marketable print literature, but whose print products depend on support by NGOs or Christian missions, either are not found at all on the web or only on websites edited by NGOs, e.g. Dinka (Agamlön Online), or Christian churches (e.g. Watchtower).

Despite the reluctant use of the internet possibilities by the majority of African languages, a novel striking development in the use of the internet as a medium of written communication can be observed with regard to some non-standard languages. The so-called "street languages" Sheng and Engsh (Kenya, Tanzania) and urban Kikongo, a Kikongo-French mixture, are used in online-forums (Kinshasa/ Brazzaville). ${ }^{24}$ Sheng and Engsh are used, e.g. in the Kenyan blogs "Nairobi back in the day", and urban Kikongo is used in some forums of "Ne-Kongo" forums. In their development they apparently have skipped the stage of print media. With regard to Sheng its use in forums also indicates that the alleged low degree of standardization (cf. Mufwene, online ${ }^{25}$ ) is not felt by the users.

Another astonishing development, at least from an economic point of view, is the creation and offer of fonts for almost all African scipts. Fonts are offered by various private enterprises (e.g., Bekere, Ager, Glavy, ziva) even for the ancient scripts and for the modern African scripts (ch. 3.3.), including the obsolete Kpelle script. This corroborates with the fact that many of these scripts are currently enjoying a revival process.

For the time being, the Latin script as a medium for African languages is definitely better presented on the web than Ajami. With regard to Swahili and Hausa ${ }^{26}$ this may partly be ascribed the influence of the websites hosted by American universities (Kamusi-Project, Hausa Home Page, K'ofar Hausa) but even more to the websites of the short-wave radio stations like Deutsche Welle, BBC and VOA, which produce an enormous amount of online information in Latin script. The use of both Latin script and Ajami is supported by initiatives whose target is to promote the use of African languages in the internet.

\subsection{Bisharat}

The Bisharat panAfrican localisation project is an initiative aiming at enhancing development by means of the developing African vernacular languages and make them means of electronic communication. Bisharat promotes the Latin script and the development of additional special characters for the production of online texts. The target is to empower African nations with regard to the global market. 


\subsection{ALMA}

The African Language Materials Archive (ALMA), coordinated by John Hutchison, is a collaborative project initiated by several West African, American and international institutions, e.g. West African Research Association (WARA), West African Research Center (WARC), UNESCO, Columbia University and the Digital Library of International Research (DLIR). The ALMA project is a web-based electronic archive of original materials published in African languages. As it grows, ALMA will be an increasingly valuable resource for teachers, literacy trainers, readers, language learners and scholars.

Both ALMA and DLIR promote the use of Ajami, and a collection of texts in various West African languages written in Ajami is in progress. In summer 2006, Fallou Ngom (2005) intended to go to Senegambia and collect texts written in Ajami. In beginning of September 2006, the DLIR online archive contained, however, only texts written in Roman script.

\section{Writing in Sango}

The preceding chapters investigated on the use of the Roman script with regard to African languages in general. The following chapter focuses on its use in one particular language, Sango. It discusses the development of Sango as a written language from the introduction of the Latin alphabet until the use of the language on the web.

\subsection{Emergence of Sango}

Sango is the national language of the Central African Republic (CAR) and since 1991 it is also next to French the official language. The language emerged in the last decade of the $19^{\text {th }}$ century as a result of the Belgian and French colonial expansion in the Ubangi bend in a situation of intensive language contact. Apart from the lexifier Ngbandi, the most important languages involved were, Lingala, Kikongo and French.

Sango plays a minor role in the studies on language planning in Africa, although its role in the language policy in the Colony Ubangi-Shari and later in the Central African Republic is better documented than that of many other African languages. Therefore it was chosen for a case study on which to demonstrate success and failures of alphabetization in the Roman script. It is a typical example of a language in francophone Africa which was reduced to writing in Latin script, although single steps in this process are specific for Sango. It will, however, become clear that some of the stereotypes on how the French colonial administration treated African languages and in what way it differed from the treatment by the British colonial forces do not match the historical reality.

Within a short period of time after its emergence, Sango gained considerable importance which made it necessary for the colonial administrators and European traders and salespersons to have at least some knowledge of the language. In order to enable them to learn Sango the Colonial Ministry of France edited Giraud's dictionary of Sango, Kikongo and Zande in 1908. It appeared first in the Revue Coloniale and then as a monograph. The target of the book is quite clearly shown in the introduction: "Ce vocabulaire est destiné aux fonctionnaires chargés de l'administration des indigènes, ainsi qu'aux commerçants. II a pour but de leur faciliter la connaissance des principaux dialects du Congo, et de les aider ainsi dans l'accomplissement de leur mission." The publication of a number of further dictionaries and grammatical descriptions by Catholic missionaries, Calloc'h (1911), Clerc (1911), Eboué (1918), Gérard (1930), Kerux E. San-Youen (1950) and Tisserant (1950) confirms the need for information on Sango. 


\subsection{Competing orthographies}

Sango was first graphized in Roman script, but from the beginning both Latin and French orthographies were used. ${ }^{27}$ There were five vowels, $\left.<\mathrm{a}, \mathrm{e}, \mathrm{i}, \mathrm{o}, \mathrm{u}\right\rangle,\langle\mathrm{g}\rangle$ for the voiced velar plosive in any environment, < ny $>$ is written for the palatal nasal is written and $\langle n g\rangle$ for the prenasalized velar plosive, giving, e.g., míngi or migi 'much, many, súkúlà 'wash', fútà 'pay', hõ 'nose', and nye 'what?'. In the French orthography the five oral vowels are written $\langle a, e, i, o, o u\rangle$, nasal vowels, which are not marked in the Latin orthography are now marked by a subsequent $\langle n\rangle$; the palatal nasal is again marked by $\langle n i>$, the prenasalized palatal fricative the prenasalized velar plosive by $\langle n g>$; and voiced velar plosives before high vowels marked by the digraph $<g u>$, e.g., mingui, soukoula, fouta, hon, nie etc. Neither the Latin nor the French orthographies mark tone.

The French orthography was used for the first translations of the Bible: 1936 in the New Testament by the Baptist Mid-Mission and in 1957 in the Catholic Bible. This choice of orthography astonishes since it took place quite some time after the conferences in Congo (1924) and Sudan (1928), where the unification of African orthographies on an international level was discussed, which should be based on the English consonants and Italian vowels.

The choice of the French orthography by the French Catholic and the American Baptist Mid-Mission shows that they cared more for a unified orthography in the French dominated area where Sango and French were written than for agreements with other colonies. According to Diki-Kidiri (1977:13) the shift does not result from linguistic considerations but from the "wind of the Assimilation" blowing since 1946 from Paris via Brazzaville. He demonstrates the inappropriateness of the French orthography compared to the Latin one on the following example: mo sukula susu awe? vs. mo soukoula soussou aoué?' 'did you clean the fish?'

But long before that date, i.e. since the beginning of their stay in the territory in 1920, the American Mid-Mission deliberately had chosen the "French, or nearFrench" orthography for their publications the first of which was the above mentioned Sango New Testament. The reason for their choice was that French was the language of tuition in the national schools and that the French orthography would make it easier for readers to shift between the two languages. Their expectation materialized to a degree that "the testimony of French officials of the school system was that many more people learned to read by means of the Sango New Testament and Gospel of Saint John than through the schools." 28 (Rosenau 1980:XI)

One problem in using the French orthography for Sango consists in the marking of the degree of opening of the vowel / $e /$, which even in word final position is never silent as it is in French. While the French Catholic missionaries did not put any marking, the American (and later also the Swedish) Evangelical Missionaries used $<e ́$ > in word-final position and $<\dot{e}>$ in any other position. These distinctions were not made very systematically (cf. Diki-Kidiri (1977). The different conventions of writing $[e]$ constitute, however, only part of the differences between the writing systems of Catholics and Protestants which became increasingly apparent and motivated the designations 'Catholic orthography' and 'Protestant orthography' (Diki-Kidiri 1977:13f). ${ }^{29}$ Further differences between the 'religiolects' as (Pasch 1994) calls them, 
consist in the marking of (prenasalized) alveolar/palatal fricatives as $\langle(n) z\rangle$ by Catholics and $<(n) d j>$ by Protestants respectively and the different spelling of certain lexemes, e.g. molenge (Catholic) vs. melenge (Protestants) besides some lexical differences.

What Diki-Kidiri deplores even more than the unorthodox marking of the vowel quality by accents is the missionaries' ignorance of tone and their unwillingness to mark it even when instructed to do it. He has never accepted their counter-arguments of the low functional load of tone and that of considerable tonal variation (cf. Thornell 1994, also Bouquiaux et al. 1978:37).

In 1960 the Latin orthography - without any diacritics for marking tone or vowel quality - was used for the first translation of the Universal Declaration of Human Rights (simplified version) into Sango. The Catholics quite obviously never abandoned it, and I found it used in reprographies, e.g. a Pastoral letter from the Bishops in 1991 (Mbeti ti akota bua). In the mid eighties the Eglise Baptiste de l'Ouest also used it in some edifying booklets. ${ }^{30}$

In January 1965 the Ministry of national education of the CAR appointed a national committee which was to provide a description of the vehicular language Sango. The aim was to have a scientific basis for a new, official orthography for Sango which would replace the various existing spelling systems. The assistance of a linguist, Luc Bouquiaux, should ensure a high scholary standard of the project. (Bouquiaux 1978:13). ${ }^{31}$ A condition was that the new orthography would be easy to use on standard French typewriters, the only ones available in the country. Special characters and diacritics had to be avoided in favour of digraphs, e.g., for the marking of nasalized vowels. Bouquiaux (1978:37) suggested to neglect tone marking with the argument of the low functional of tone and of considerable tonal variations between the different dialects. This allowed him to use the accents for marking of vowel quality and to distinguish seven vowels, e.g., <a, e, é, i, $\hat{o}, o, u>$ for $/ a, \varepsilon, e, i$, $0,0, u / .^{32}$

The dictionary appeared in 1978. Entries are listed in alphabetical order in the proposed script. Phonemic transcriptions with phonetic symbols and each syllable marked for tone follows each entry in square brackets. Being printed in bold type these phonemic entries are more salient to the reader than those in the proposed orthography. In the introductory chapters on phonology (30-34), tonology (34-38), language engineering, i.e. compounding, borrowing and derivation (42-49), all examples are given in phonemic writing. The only exception is the in chapter on the transcription of loanwords (39-42) in which they are presented in the proposed orthography, followed by a phonetic transcription.

In the dictionary Bouquiaux et al. not only introduced a new orthography, but also an enormous amount of new technical terminologies from a wide range of technical and scientific disciplines. These were to form major steps towards the development of the Sango as a medium of learning and instruction and for scholary publications. Many of these terminologies had not been observed in communicative situations or elicited from specialists of the various disciplines. They were rather created by the authors of the dictionary according to the word formation rules of Sango and its lexifier language Ngbandi (44-49) and lexicon mainly from Ngbandi, Banda, Gbaya, Ngbaka and Zande.

When editing the dictionary the authors had good reasons to believe that intensive language programs would be organized and that the terminologies of their 
plumes were diffused through school education. Unfortunately the economic situation in the country changed drastically so that the envisaged programs had to be cancelled, and there was no foreign support to help disseminate the new orthography and terminology.

Even though the proposed orthography was created at the request of the Central African Government and in spite of an imperial ordinance in February 1977 according to which the official orthography of Sango was fixed (cf. Koyt 1994:19), it was never implemented. Diki-Kidiri (1977:52f), himself member of Bouquiaux' team, states: "C'est ainsi que l'alphabet officiel du sango national est né ... sur le papier, et y est resté!" He continues that the orthography does not allow to mark tones with ordinary French typewriters and suggests a revised phonolical orthography. It differentiates seven vowels, has obligatory tone marking (acute $=$ high, grave $=$ low, horizontal dash above vowel = mid, circumflex (â) = falling, inflex (ă) = rising tone), and a rule that in series of syllables having identical tone, it is marked only in the first instance. Except for the obligatory marking of tone this orthography reflects the phonemic writing in Bouquiaux et al.'s dictionary. A collection of texts at the end of the book promise to serve as input for future authors. They are probably the only texts ever published in that orthography. The orthography did not fulfil Diki-Kidiri's major target.

Neither open vowels $[\varepsilon]$ and [0] could be written on standard French typewriters nor the inflex (marking rising tones).

In Kua tî ködörö - Le Devoir National, Diki-Kidiri (1982:1-28) again presents a new orthography. In his introduction to the writing system, he stresses that in order to facilitate easy and correct reading of Sango it is indispensable to mark two different linguistic categories: phonemes and tones. According to him, the distinctive function of tone in Sango is higher than that of the degree of openness of vowels. In order to solve the problem of marking tone and have the orthography manageable on standard typewriters he suggests to reduce the number of vowel graphemes to five and to distinguish only three simple tones: high (circumflex, e.g. mbênî 'some, INDEF'), mid (diaeresis, e.g. ködörö 'home, village, country') and low (unmarked, e.g., lo 'he/she'). For modulated tones he resorts to the solution of Bouquiaux et al. (1978) and decomposes them on two subsequent vowels, which allows to differentiate three modulated tones: 1) rising, e.g., taâ 'true, real', 2) high-low falling, sêe 'bitter' and 3) mid-low falling, e.g. pëpëe 'not' (Diki-Kidiri 1982:1-19).

\subsection{Print production}

Even before the newly designed orthography was officialized, the first two books had been launched: the above mentioned Kua tî ködörö and Sêndâmâti - Mathématiques (Trenel et al. 1982). Two volumes of the Lexiques Thématiques de l'Afrique Centrale (ACCT 1983, 1984) and a reader Ë tene Sängö ('We speak Sango') by C. Loma (1984) followed shortly after. A further publication was edited by SIL (s.d.): Akobêla awü töngana nye? ('How do illnesses spread?'). All of these publications address specialized readerships, but they remained isolated publications which could not initiate a habit of reading reference books in Sango and make the reader comfortable with the orthography. Entertaining texts for the general public, like novels, short stories and historical tales which could fulfil that function were not produced. Only few 
publications by missionaries were written in the official orthography. The multicopied Grammaire Sango by Huguin (1990) is probably the only Catholic production. S.I.L. published a series of children's booklets, only one of which indicates the year of production, 1991. In cooperation with the Ėglise Baptiste de l'Ouest and the Grace Brethren Mission ${ }^{33}$ they had trained authors to apply the new orthography. The Baha'i community, in 1990 a quite active religious group in Bangui, then also used the official orthography.

Despite the introduction of the official script the old orthographies are used until today. In the early 1980s 'Linga', a bimonthly journal published by the Institut Pédagogique Nationale, was written in Latin orthography, distinguishing seven vowels, open vowels being marked by diaeresis, and without tone marking. Texts of the Catholic missions are usually written in Latin orthography, only a small number is written in French orthography. Some of these publications show accents marking for open and closed vowels, while in others tones accent serves to mark tone occasionally or regularly. The majority of Protestant texts use the Latin orthography, distinguishing five vowels and without tone marking and. Occasionally they have accents on the vowel $[e]$.

Among expatriates in the CAR, in particular the missionaries who produce the majority of print publications, the new official orthography was quite generally not welcome. Christina Thornell (1994), who in recognition of the language policy quite meticulously applies it on examples in her own studies, gives a thorough analysis of its advantages and disadvantages. She considers in particular the obligatory tone marking as problematic. Another reasons why missionaries are reluctant to apply the new orthography to prayers and religious texts, is their feat that such a drastic change of spelling might cause the believers' doubts about the contents. For this reason a new edition of an important document as the Bible is therefore out of question. ${ }^{34}$ It might be regarded no longer as the "Bible of our forefathers", characterized by a divine language. The missionaries see the risk that the believers doubt so badly that they end up leaving the church. This apprehension corroborates perfectly with Fishman's (1988:280) statement about the replacement of writing systems (ch. 3.2.).

Unfortunately the aim of the orthography reform, to increase literacy among the population, was not achieved. No publication was made for the market. Gerbault $(1988: 8)$ states that while radio broadcasts in Sango are extremely popular and cover more than $65 \%$ of the program, it is fairly difficult to make the language a medium of marketable print publication. It is true that obligatory tone marking makes writing difficult, but it does not affect readability and by consequence cannot explain the widespread lack of interest in the print productions in Sango.

Projects to increase literacy were carried out widely unnoticed. Only few residents of Bangui, capital of the CAR, knew about the Sango journal 'Linga'. This general nescience can be explained by the fact that this journal did not satisfy needs, despite a very active and publicly recognized pro-Sango policy and despite Sango's success as language of the radio. Linga's dependence on foreign funding and an edition of only 5.000 copies confirms the assumption that there was no demand of a potential readership (Gerbault 1988:7).

\subsection{Immobile inscriptions}

Inscriptions on stationary objects (cf. Reh 2004) hardly play a role with regard to Sango. Robert Beyom (online) gives only one example: a fairly old notice board prohibiting access to a military camp: TERRAIN MILITAIRE. ACCES REGLEMENTE - NDO TI A TOUROUGOU. ZO A LI KIRIKIRI PEPE. ${ }^{35}$ A famous quotation from 
Boganda $^{36}$ on the coat of arms, ZO KWE ZO, ('all people are equal') may serve as a second example.

The contents of the two inscriptions confirm observations made in South Africa that inscriptions in African languages on stationary objects, posters and flyers tend to be warnings and prohibitions, while useful or positive information is given in English and/or Afrikaans. Political slogans in African languages like batho pele 'people first' (Sepedi) constitute rare cases of friendly texts (Pasch 2000).

\subsection{Sango on the Internet}

The marginal role of Sango as a means of written communication in the internet reflects its use in print publications. Books and webpages in Sango are produced almost exclusively by religious organisations, e.g. the 'Watchtower' by Jehova's Witnesses, and international political organisations, e.g. the 'Universal Declaration of Human Rights' (full version, now in the official orthography) by the United Nations. Private initiatives, like YBS, Yângâ tî Sahngo tî Bêafrîka, are exceptional with regard to African languages. A unique feature of the the YBS-site is its use as a platform on which a new orthography is presented.

\subsection{Proposal of a new orthography}

When he launched the YBS-website, Diki-Kidiri hoped that Central Africans in the diaspora would use it to get regular input in Sango and might use the language for their own personal editing of texts. This wish was only partially fulfilled. The number of the visitors of the site is moderate, and most contributions in the forum, as in the forums of some other Central African websites are written in French. Contributions in Sango are restricted to questions about this very language, and even here part of the contributions are written in French.

The authors who do write their contributions in Sango struggle with the orthography. Some use an orthography closer to the Latin one, others one which is closer to the French, hardly anybody mastering the official orthography, not with regard to spelling and even less with regard to tone marking, which does, however, not have an affect on the comprehension. A few sentences from different contributions in different forums shall illustrate the "deviation" from standard orthography. They are supplemented by and transliterated into the official orthography, provided with glosses and a translation.

1. Singuila mingui na mo na kota koua So

singîla mîngi na mo na kota kwa Sô

thanks much PREP 2s PREP big work DEM

$\begin{array}{llllllllll}\text { mo } & \text { ké } & \text { sala } & \text { ti Tènè } & \text { yanga } & \text { ti } & \text { kodro } & \text { ti } & \text { yé } & \text { a Maï } \\ \text { mo } & \text { yeke } & \text { sâra } & \text { Tîtene } & \text { yângâ } & \text { tî } & \text { ködörö } & \text { tî } & \text { e } & \text { a-mâi } \\ \text { 2s } & \text { COP } & \text { do } & \text { so.that } & \text { language } & \text { SUB } & \text { country } & \text { SUB } & 1 p & 3 s \text {-develop }\end{array}$
Thank you very much for the great job you are doing to make our country's language develop.

2. Singila mingi na ala. kusala ti ala. Ayeke pendere mingui singîla mîngi na âla kosâla tî âla a-yeke pendere mîngi thanks much PREP $2 p$ work SUB $2 s$ 3s-COP beautiful Very Thank you (pl) very much. Your work is very good.

3. Balao mingui, nguia a si $\mathrm{Be}$ ti $\mathrm{mbi}$ ti fono, balao mîngi ngîâ a-sï Bê tî mbï tî fono hallo much joy 3s-fill heart POSS $1 \mathrm{~s}$ SUB stroll 


$\begin{array}{llllllll}\mathrm{Na} & \mathrm{ti} & \text { tamboula } & \text { na } & \text { Ya } & \text { ti } & \text { lendo } & \text { so } \\ \mathrm{Na} & \text { tî } & \text { tambûla } & \text { na } & \text { Yâ } & \text { tî } & \text { lêndo } & \text { sô } \\ \text { PREP } & \text { SUB } & \text { walk } & \text { PREP } & \text { Heart } & \text { SUB } & \text { site } & \text { DEM }\end{array}$

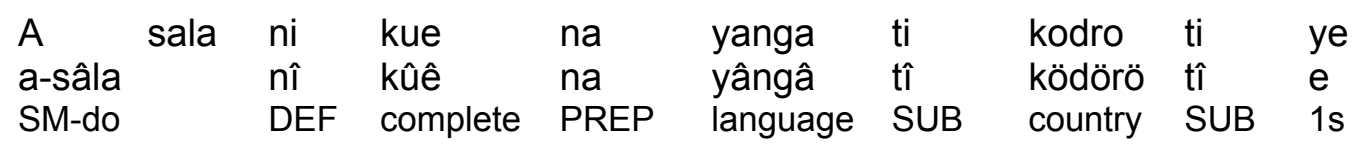

Hallo. My heart is full of joy to visit and browse on this site that was made completely in the language of our country.

Although the official orthography is not mastered by the contributors, it is highly recognized and never questioned. This behaviour clearly indicates that an orthography is more likely to be accepted if its designer is a native speaker of the language and a national of the country where a language is spoken, than if it is the product of foreign design. It furthermore shows that the appreciation of an orthography need not correlate with its mastery.

In 2001 Diki-Kidiri declared that this official orthography had be "un système stable, pour qu'on ne soit pas constamment obligés de faire des réformes orthographiques." This argument reflects Fishman's (1988:280) hypothesis concerning reactions to replacements of writing systems. Nevertheless, in 2006a and b Diki-Kidiri proposes a noticeable modification of the official orthography on the YSB-website (completely transliterated in May 2006) with the target to have more economical tone marking rules. Since the marking of simple and modular tones has not changed, only the new tone rules are given here:

In series of identical high $\left(^{\wedge}\right)$ and mid $\left({ }^{*}\right)$ not all single tones are marked, but only the beginning and the end of the series.

1 The first in a series of identical high or mid tones $/ \mathrm{h} /$ [called 'tonal $\mathrm{H}^{\prime}$ ] is indicated by the insertion of an /h/ ('tonal $\mathrm{H}^{\prime}$ ) after the first syllable vowel if the second syllable begins with a complex consonant, e.g. sahngo 'Sango-language' and sêhndayanga 'linguistics' instead of sängö and sêndâyângâ.

2 If the second syllable begins with a simple consonant, the beginning of the tonal series is indicated by a gemination of that consonant, e.g. tassema 'class, ranking' instead of täsëmä and târrawara 'transparent' instead of târâwârâ.

3 The end of the tonal series is indicated by the end of the word, a hyphen or the marking of a following different tone, e.g. mbetti 'letter' instead of mbëti,

hihngango-ndo 'knowledge, culture' instead of hïngängö-ndo and tohndorozôro

'tincture of iodine' instead of töndörözôro.

Diki-Kidiri is right in that these rules want less marking of tones than the official orthography, but that only seems to be an advantage. It cannot be denied that such tone-marking rules are highly complicated, notwithstanding the problem of the considerable tonal variation of tone in Sango. From a linguistic and pedagogical point of view the introduction of these rules would not really mean an improvement.

Given that, as claimed above (ch. 3.2.), under convenient conditions any reasonable orthography can be used effectively, this must also hold true for the present official orthography and also for the one currently proposed, despite their deficiencies. In other words, the degree of alphabetization and literacy of a population 
depends less on the linguistic quality of the given orthography than on the general educational level and the amount of regular input of written text that they get.

In he CAR there is no good chance for any orthography to be generally mastered and used as long as the following conditions hold true: 1) a big part of the population is illiterate, 2) marketable literature in Sango is not available, and 3) Sango is not continuously used on flyers, pamphlets, billboards and other written public announcements, hence there is no linguistic landscape in Sango.

There is, however, another sociolinguistic argument with regard to the question of orthography in CAR which must not be ignored: Diki-Kidiri's exclusive authorship of the orthography. He is the best trained linguist of the nation, and his work has an enormous prestige among his country-fellows in CAR and in the diaspora. They highly appreciate his great efforts on behalf of the Sango orthography, and so does the Government who gave the 1984 version an official status. The appreciation is irrespective of whether the orthography is mastered or not. It is hardly conceivable that the work of a foreign linguist can receive the same recognition for his or her work on Sango. This constitutes a sociolinguistic situation where it is a political condition sine qua non to have Diki-Kidiri involved in any project concerning the development of Sango.

\section{Conclusion}

I has been shown that in Africa since ancient times scripts have been in competing situations similar to those of the languages concerned. Fishman's (1965) fundamental sociolinguistic questions concerning oral communication "Who Speaks What Language to Whom and When" want an extension: "Who Writes What content in Which language in What script, on What medium and When." These questions outline the subdiscipline 'sociolinguistics of writing' (cf. Coulmas 2003).

Roman script, at present the most important writing system on the African continent, was the first writing system which was introduced from abroad with the aim of disseminating it over the entire continent. It should be the medium for graphizing local languages, alphabetize the population and make them literate in their mother tongues. These targets could be achieved only to some degree. Many languages were never given orthographies, the graphization of many other African languages did not turn them into media of learning and literacy, and a production of literatures of all genres remains a desideratum. In the course of time this has lead to a number of reactions which include the following:

- lack of interest in mother tongue education and reluctance to buy and read books in African languages

- the improvement (non-recurring or recurring) of the given orthography, based on the hope that a better orthography will lead to widespread literacy and economic growth

- the design of new scripts, independent of the Roman and Arabic models, which should make its users independent of and competitive with the Europeans

- the revival of writing systems which had been partly replaced by the Roman script, e.g. Ajami, Tifinagh and Bamum

The first reaction is one of resignation, while the latter three express strong efforts to mark the respective linguistic groups' independence from imported conventions which are not considered useful. An independent orthography, allowing the publication of texts which cannot easily be controlled by outsiders, may also symbolize an opposition to the language policy of the government. This is true for Tifinagh and Oromo. The replacement of an imported orthography by a native linguist, as in 
Sango, is a different type of demonstration that linguistic expertise of foreigners is not appreciated when it is available in the country.

An important sociolinguistic criterion of a different type which may decide upon the acceptance or rejection of an orthography is its authorship. The official orthography for Sango designed by Diki-Kidiri is highly appreciated by many citizens of Central African Republic, irrespective of whether hey master it or not. The same is true for his proposal of a modification of this orthography.

The specific design of an orthography in itself does not decide whether it is accepted or not as medium of written communication by the speakers concerned. The orthographies of English, French and German are reasonable writing systems, but for centuries they have been far from constituting ideal phonological systems. This substantiates the assumption that continuous input of new written information is a necessary condition to uphold the literacy of the population. The input may come from books, journals and newspapers, but people who do not read longer texts depend on a written landscape, i.e. an overall daily input through all kinds of written information to be kept constantly practicing their reading competence.

Why should it not be true for Africa that any reasonable orthography allows access to literacy? What is important is that reading competence, once it has been acquired, is not lost in a later stage. The easy availability of attractive reading material, for which people are as much ready to pay as for cigarettes or cinema entrance fees, is a sine qua non. This may be entertaining literature for the one, technical reference books, for the other, and newspapers and journals for everybody. A linguistic landscape can assure at least a passive competence in any orthography.

If input is insufficient and/or given in different orthographies, readers and writers will be insecure about spelling rules, even if reading comprehension is not affected. This can be observed in the online forums for Sango. Of course, it makes sense to design orthographies which are both phonological, i.e. easy to learn, and economic, i.e. easy to write by hand and to type with the technical facilities available. But once an orthography has been accepted by a population or by part of a population and acquired to some degree, it is easier to implement it further than to replace it.

With regard to Sango, neither the co-existence of Catholic and Protestant orthographies nor the neglect of tone marking is a serious problem for the readability of texts. A problem is rather the general lack of interesting texts, and in particular of texts in the official orthography. Without model texts authors cannot get sufficient input of that orthography to be competent in it. The consequence is a second case of 'orthographic anarchy' (ch. 3.2.): spelling differs from one text to the next, occasionally even within publications by the same congregation, and irrespective of whether the orthography is closer to that of Latin or of French.

\section{Sources}

ACCT, CERDOTOLA \& I.N.E.F. 1983

Lexiques thématiques de l'Afrique Centrale 1. Activités économiques et sociales. Paris

ACCT, CERDOTOLA \& I.N.E.F. 1984

Lexiques thématiques de l'Afrique Centrale 2. Education et formation. Paris

Agamlön Online, s.d.

'Kudual, welcome!' (About the Dinka language Institute), http://home.vicnet.net.au/ agamlong/index.en.html (30.08.2006)

Ager, Simon, online

Omniglot. Writing Systems and Languages of the World, http://www.omniglot.com/index.htm (30.04.2006) 
Albaugh, Ericka, online

The colonial image reversed: a new politics of language in African states, http://socsci2.ucsd.edu/ aronatas/scrretreat/Albaugh.Ericka.doc (15.06.2006)

Amazighweb.com, online 'Bienvenue sur les forums de Amazigh Web', http://www.amazighweb.com/modules/newbb/index.php (30.04.2006)

Anonymous, s.d.

A brief sketch of the beginning and the development of the Grace Brethren Mission in Central Africa. (multicopied) s.I.

Anonymous 2002

On refusing to read your own language. Languagehat, http://www.languagehat.com/archives/000454.php (30.04.2006)

AODL (African Online Digital Library) 'Diversity and Tolerance in the Islam of West Africa: Creating Online Resources of Peaceful Muslim Practice', http://www.aodl.org/ticfia/collaborators.php (11.05.2006)

Asher, R.E. (editor-in-chief) 1994 The Encyclopedia of language and linguistics. New York: Pergamon Press

[The] Bassa Vah Association, online 'The Bassah "Vah" alphabet', http://www.ie-inc.com/vkarmo/bcont.htm (17.05.2006)

Battestini, Simon 2004 'African Writing Systems, Texts and Cultural Identities,' TRANS. Internet-Zeitschrift für Kulturwissenschaften 15, http://www.inst.at/trans/15Nr/01 2/battestini15.htm (28.09.2006)

Baumgardt, Ursula \& Bounfour, Abdellah (eds.) 2000 Panorama des littératures africaines. État des lieux et perspectives. Paris: L'Harmattan/INALCO

BBC World Service, online) 'Newspapers.' In: The Story of Africa, between the World Wars (1914-1945), http://www.bbc.co.uk/worldservice/africa/features/storyofafrica/13chapter7.shtml (24.08.2006)

Bechhaus-Gerst Marianne1996

Sprachwandel durch Sprachkontakt am Beispiel des Nubischen im Niltal. Möglichkeiten und Grenzen einer diachronen Soziolinguistik. Köln: Köppe

Bekerie, Ayele, Anika lesha Daniels and Josph Egbulefu 1996 'African Writing Systems', Africana Library homepage, Cornell University, http://www.library.cornell.edu/africana/Writing Systems/Welcome.html (17.05.2006)

Ben-Rafael E., Shohamy E., Hasan Amara M., Trumper-Hecht N. 2004 Linguistic Landscape and Multiculturalism: A Jewish-Arab Comparative Study. Tel Aviv, The Tami Steinmetz Center for Peace Research Tel Aviv University

Beyom, Robert (, online)

Les langues des écriteaus en République centrafricaine.

http://www.bibliotheque.refer.org/livre244//24425.pdf (20.06.2006)

Bilisummaa, online

Oromia - Oromiyaa, http://www.bilisummaa.com/ (17.05.2006)

Bisharat

'Réunion d'un groupe d'experts pour l'unification des alphabets des langues nationales, Bamako (Mali), 28 Février - 5 mars 1966, Rapport final', http://www.bisharat.net/Documents/Bamako1966.htm (17.05.2006) 
Bouquiaux, Luc, Jean-Marie Kobozo \& Marcel Diki-Kidiri 1978

Dictionnaire. sango-français. Paris: SELAF

British Library, online

'Bamum script and archives project: saving Africa's written heritage', Endangered

Archives, http://www.bl.uk/about/policies/endangeredarch/tuchscherer.html (25.08.2006)

Bromber, Katrin 2002

'German Colonial Administrators and the Promotion of Swahili at the Seminar of Oriental Languages in Berlin', Sahara Studies Association Newsletter, November Vol. 10,2, http://www.saharanstudies.org/news/newsletters/v10n2.pdf, (15.04.2006)

Browne, Gerald M.1989

Introduction to Old Nubuan. Meroitica II. Berlin: Akademie-Verlag.

Calloc'h J. 1911

Vocabulaire français-sango et sango-français de l'Oubangui-Chari : précédé d'un abrégé grammatical. Paris: Geuthner, 1911

Clerc M. 1911

Grammaire Sango. Bulletins et Mémoires de la Société d'Anthropologie de Paris

Coulmas, Florian 1991

The Blackwell Encyclopedia of Writing Systems. Oxford: Blackwell

Coulmas, Florian 2003

Writing Systems. Cambridge: Cambridge University Press

Dalby, D. 1986

'L'Afrique et la lettre', in: Africa and the Written Word. Exhibition Catalogue. Ed. by

Centre Culturel Français, Lagos and Fête de la Lettre. Paris

Delafosse, Maurice 1899

'Les Vai leur langue et leur systeme d'ecriture,' L'Anthropologie 10

Dewees, John 1977

'Orthography and identity: movement toward inertia.' Language and Linguistic Problems. Proceedings of the VII conference on African Linguistics, ed. by Paul A.F. Korey and Haig Der-Houssikain, pp.120-131. Columbia, SC: Hornbeam Press

Digital Library for International Research

http://www.aiys.org/aodl/public/access/alma ebooks/index.php (04.09.2006)

Diki-Kidiri, Marcel 1977

Le Sango s'écrit aussi ... . Paris: SELAF

Diki-Kidiri, Marcel 1982

Kua tî ködörö - Le devoir national. Mbëtï tî hînga na sêndâ lëkëngö-ködörö introduction à l'instruction civique. Paris: SELAF et ACCT

Diki-Kidiri, Marcel 2001

'MDK, auteur de la loi ?',

http://www.swisstools.net/forum/result.asp?fid=3985\&id=31169\&tb=2 (02.06.2006)

Diki-Kidiri, Marcel 2006a

'Guide de l'orthographe Sahngo' (Document de travail). YSB Sahngo, http://sango.free.fr/ (25.05.2006)

Diki-Kidiri, Marcel 2006b

'L'accès au cyberespace des les langues peu dotées', paper presented at the ITU and UNESCO Global Symposium on Promoting the Multilingual Internet, Geneva, 9-11 May 2006, http://www.itu.int/ITU-T/worksem/multilingual/papers/sintro-paper-diki-kidiri.pdf (04.09.2006)

Diki-Kidiri, Marcel, online 
YSB. Yângâ tî Sahngo tî Bêafrîka, http://sango.free.frl (01.06.2006)

Diki-Kidiri, Marcel and Edema Atibakwa Baboya 2003

'Les langues africaines sur la toile'. Cahiers du Rifal 23:33-45,

http://www.rifal.org/cahiers rifal/rifal23.pdf\#search=\%22haousa\%20boko\%20toile\%22 (30.08.2006)

Easton, Peter and Mark Peach 1997a

The practical applications of Koranic learning in West Africa, document prepared for the ABEL Project, http://pdf.dec.org/pdf docs/Pnacj812.pdf (15.05.2006)

Eboué, A.F. 1918

Langues sango, banda, baya, mandjia. Paris: Larousse.

Encyclopaedia of the Orient, s.d.

The only encyclopaedia for North Africa and the Middle East, http://i-cias.com/e.o/ (02.08.2006)

Encyclopedia Britannica online, s.d

'Jabavu, Davidson Don Tengo', http://www.britannica.com/eb/article-9043127

(02.08.2006)

Everson, Michael, online

'Osmanya Script: The first and the only Somali invented writing script,' http://www.somalinet.com/library/osmaniya/, (25.08.2006)

Everson, Michael, Charles Riley \& José Rivera 2005

'Proposal to add the Vai script to the BMP of the UCS', International Organization for Standardization, ISO/IEC JTC1/SC2/WG2 N2948R, L2/05-159R, 2005-08-01, http://www.library.yale.edu/international/documents/riley05.pdf (25.04.2006)

Fallou Ngom 2005

'The secular usage of Ajami writings in Senegal,' WARA's Spring 2005 newsletter. http://web.africa.ufl.edu/WARA/alma news.htm (05.09.2006)

Fishman, Joshua .A. 1965

'Who Speaks What Language to Whom and When', La Linguistique 2:67-88.

Fishman, Joshua A. 1988

'Ethnocultural issues in the creation, substitution, and revision of writing systems.' In:

The Social Construction of Written Communication, ed. by Bennett A. Rafoth and

Donald L. Rubin, pp. 273-286. Norwood, NJ: Ablex

Forbes, F.E. 1957

'Despatch communicating the discovery of a Native written character at Bolmar on the western coast of Africa, near Liberia, accompanied by a vocabulary of the Vahie or Vei tongue', with notes on the Vei language and alphabet by E. Norris', Journal of the Royal Geographical Society 20:89-113

Fourah Bay College - University of Sierra Leone (FBCUS), online 'Brief history of Fourah Bay College', http://fbcusl.8k.com/history.htm (30.04.2006)

Frankl 1998

'Review of Tarjama ya al-Muntakhab katika Tafsiri ya Qur'ani Tukufu', British Journal of Middle Eastern Studies 25:191-193

Galand, Lionel [1973] 2004

'Libyque et berbère', in: Annuaire de l'Ecole Pratique des Hautes Etudes, IVe section, pp. 173-79. Online-edition in 2004 by Agafay, Bennana,

http://sd606.sivit.org/asays/article.php3?id article=323 (30.04.2006)

Gamta, Tilahum 1992 
'Afaan Oromo', paper at the 1992 Oromo Studies Conference, and published in the Journal of Oromo Studies,

http://www.africa.upenn.edu/Hornet/Afaan Oromo 19777.html (15.05.2006)

Gerbault, Jeannine 1988

'Utlisation des langues et attitudes: ma montée du sango', Bulletin de l'Observation du

Francais Contemporain en Afrique Noire. Paris: CNRS

Gérard, Marcel 1930

Sango, langue commerciale de l'Oubangui-Chari. Rome: Saint-Pierre-Claver

Giraud, Gaston 1908

'Vocabulaire des dialectes Sango, Bakongo et a-Zandé.' Revue Colonial (Ministère des Colonies), Nouvelle Série 58, Jan., http://visualiseur.bnf.fr/CadresFenetre?O=NUMM67143\&M=tdm, (06.05.2006), reedition (1908) Paris: Ministère des Colonies, Augustin Challamel (cit. in Samarin 1982)

Glavy, Jason, online

African Fonts, http://www.geocities.com/jglavy/african.html, (15.07.2006)

Gordon, Raymond G., Jr. (ed.) 2005

Ethnologue: Languages of the World, Fifteenth edition. Dallas, Tex.: SIL International. Online version: http://www.ethnologue.com/ (15.05.2006)

Grzymski Krzysztof 1983

'The Meroitic Mystery. From Nubia - the land of Kush - a language lost in history', Saudi Aramco World July/August 1983:22-23,

http://www.saudiaramcoworld.com/issue/198304/the.meroitic.mystery-

from.nubia.the.land.of.kush.a.language.lost.in.history.htm

Haacke, W.H.G. 2005

'Linguistic Research for literary empowerment of Khoesan languages of Namibia'.

African Studies 64,2:157-176

Haarmann, Harald 1990

Universalgeschichte der Schrift. Frankfurt/New York: Campus Verlag

Hair, P.E.H. 1967

The Early Study of Nigerian Languages. Cambridge: Cambridge University Press

Hashim, J. A. 2004

'Competing Orthographies for Writing Nobiin Nubian,' Occasional Papers in the Study of Sudanese Languages 9. Entebbe: SIL/Sudan

Hayward, R.J., and Hassan, Mohammed 1981

'The Shaykh Bakri Sapalo Syllabary' and summary of 'The Oromo Orthography of

Shaykh Bakri Sapalo' (Bulletin of the School of Oriental and African Studies 44,3: 550-

556), http://www.abyssiniacybergateway.net/fidel/ShaykhBakriSapalo/ (30.04.2006)

Hausa Home page, online

The UCLA Hausa home page, http://www.humnet.ucla.edu/humnet/aflang/hausa/ (30.04.2006)

Hetzron, Robert, (ed.) 1997

The Semitic Languages. New York: Routledge

Hieroglyphen-Info

http://www.hieroglyphen-info.de/index.htm (27.09.2006)

Huguin, Paul 1990

Grammaire Sango (multicopied). Bangi: Imprimerie Saint Paul

Hunwick, John 2005 
Arabic literature of Africa: Project and publication. Working Paper Series (Northwestern University, Program of African Studies, http://www.northwestern.edu/african-

studies/working\%20papers/wp13hunwick.pdf (18.05.2006)

Hutchinson, John P. 2006

'African language literature as a weapon against African language marginalization.' In:

Selected Proceedings of the 35th Annual Conference on African Linguistics, ed. by John Mugane et al., pp. 22-33. Somerville, MA: Casacilla Proceedings Project, http://www.lingref.com/cpp/acal/35/paper1293.pdf (30.04.2006)

Iro, Ismail, online

'Nomadic Education and Education for Nomadic Fulani', http://www.gamji.com/fulani7.htm (15.04.2006)

Johnson, Janet H. ${ }^{1} 1986,{ }^{2} 1991,{ }^{3} 2000$

Thus Wrote 'Onchsheshonqy - An Introductory Grammar of Demotic. The Oriental Institute, Chicago, University of Chicago,

http://oi.uchicago.edu/OI/DEPT/PUB/SRC/SAOC/45/SAOC45.html (28.09.2006)

Johnston, Harry Hamilton 1906

Liberia. London: Hutchinson \& Co.

[The] Kamusi-Project, online

The Internet Living Swahili dictionary, http://www.yale.edu/swahili/ (30.04.2006)

Kerux E. San-Youen 1950

Sango. Bangui: Mission Catholique

Kloss, Heinz 1967

"Abstand Languages' and 'Ausbau Languages", Anthropological Linguistics 9,7:29-41

Koelle, S.M. 1854

Outlines of a Grammar of the Vei Language together with a Vei-English Vocabulary. London: Kegan Paul, Trench, Trübner \& Co. Ltd.

Köpp, Dirke 2003

'Alphabetisierung im Senegal, Senegal vom 08.01. - 22.02.2003', Jahrbuch $17 \mathrm{der}$ Heinz-Kühn-Stiftung, http://www.heinz-kuehn-stiftung.de/pdf/jahrb17/jahrb17 4.pdf (30.04.2006)

Koyt, Michel Marie 1994

'La situation du Sango en République Centrafricaine.' In: Pasch (ed.), pp.13-23. Köln: Köppe

Kratochwil, Gabi 2003

Die Berberbewegung in Algerien und Marokko: Zwischen Konflikt und Kooperation mit dem Staat. DOI-Focus Nr. 12. Hamburg: Deutsches Orient-Institut im Verbund mit Deutsches Übersee-Institut

Kuhl, Wolfgang, online

'BAMOUN (Bamun, Bamoum, Bamum). Trade language spoken in most of the Noun Division, the northern area of Mifi Division and in the southeast area of Bamboutos Division, West Province, Cameroon.' http://www.christusrex.org/www1/pater/JPNbamoun.html (19.05.2006)

K'ofar Hausa, online Welcome to the Hausa-Database-Site, http://www.univie.ac.at/Hausa/oracle/KofarHausa1.html (19.05.2006), Afrikanistik Wien

Landry, R. and Bourhis, R. Y. 1997

'Linguistic landscape and ethnolinguistic vitality: An empirical study,' Journal of Language and Social Psychology 16:23-49

Languages of the World, online 
'The Nilo-Saharan language family,' National virual translation center, http://www.nvtc.gov/lotw/months/september/nilo.html (29.09.2006)

LBTC $=$ Lutheran Bible Translators Canada, online

'Duala Bukele and the tall white man', http://www.lbtc.ca/index.html (25.04.2006)

Löhr, Doris 1997

'Kanuri Orthographies from 1854 until present.' In: Advances in Kanuri Scholarship, ed. by Norbert Cyffer and Thomas Geider, pp.77-113. Cologne: Köppe

Loma C. 1984

Ë tënë Sängö - Apprenons à parler Sängö. Bangi: Ministère de l'Education nationale, République Centrafricaine

Ludwig, Frieder 1991

Kirche im kolonialen Kontext. Anglikanische Missionare und afrikanische Propheten im südöstlichen Nigeria 1879-1918. Frankfurt: Peter Lang

Mafundikwa, Saki 2000

Afrikan Alphabets, the story of writing in Afrika, m.s., summary on:

www.ziva.org.zw/afrikan.htm (25.08.2006)

Malcolm L. W. G. 1920-21

'Short notes on the syllabic writing of the EGap - Central Cameroon,' Journal of the African Society 20:127-9

Mayr Gaby 25.06.1998

'Bücher aus Afrika', [Deutschlandradio] dradio.de, http://www.dradio.de/dlf/sendungen/buechermarkt/164218/ (25.04.2006)

Mekuria, Bulcha 1995

'Onesimos Nasib's pioneering contributions to Oromo writing', Nordic Journal of African Studies 4,1:36-59

Mitchell, Larkin 1999

'Earliest Egyptian Glyphs', Archeology, A publication of the Archaeological Institute of America, http://www.archaeology.org/9903/newsbriefs/egypt.html (15.04.2006)

Mohamed Adan Ibrahim (Farkeeti), online

The Development of Maay Script, http://www.arlaadinet.com/language/The\%20Development $\% 20$ of\%20Mai\%20Script.htm (25.08.2006)

Mufwene, Salikoko S. s.a.

Contact languages in the Bantu area, http://humanities.uchicago.edu/faculty/mufwene/mufw bantucon.html (25.08.2006)

Obenga, Theophile 1999/2000

'Africa, the cradle of writing', Ankh, revue d'égyptologie et des civilisations africaines 8/9, http://www.edofolks.com/html/pub118.htm (15.04.2006)

Ne-Kongo, online

'Les Forums Ne-Kongo,' http://www.ne-kongo.net/Forum/(15.04.2006)

Nesib, Onesimus 1984

The Galla Spelling Book. Moncullo (cit. in Idris 2003)

Office of the High Commissioner for Human Rights

'DÊPÄ TÎ PÖPÖKÖDÖRÖ TÎ NDIÄ TÏ BATA NENGÖ TERÊ TÏ ZO', http://www.unhchr.ch/udhr/lang/saj.htm (30.04.2006)

Oromia online

'Oromia and the Oromo people', http://www.oromia.org/OromiaBriefs/Oromo\&Oromia.htm (30.04.2006) 
Owu-Ewie, Charles 2006

'The language policy of education in Ghana: a critical look at the English-only language polica of education.' In: Selected Proceedings of the 35th Annual Conference on African Linguistics, ed. by John Mugane et al., pp.76-85, Somerville, MA: Casacilla Proceedings Project, http://www.lingref.com/cpp/acal/35/paper1298.pdf (30.04.2006)

PanAfrLoc, online 'ArabicScript' (http://www.bisharat.net/wikidoc/pmwiki.php/PanAfrLoc/ArabicScript), in: Enhancing capacities for ICT in Arabic and African languages. PanAfrican Localisation, http://www.bisharat.net/wikidoc/pmwiki.php (30.04.2006)

Pankhurst, Richard P.K. 1968

An Economic History of Ethiopia, 1800-1935. Addis Ababa: Haile Selassie I University Press

Pasch, Helma 1994

'Religiolekte des Sango.' Perspektiven afrikanistischer Forschung. Beiträge zur Linguistik, Ethnologie, Geschichte, Philosophie und Literatur. X Afrikanistentag Zürich, 23.-25.09.1993, hrsg. von Thomas Bearth, W.J.G. Möhlig, Beat Sottas und Edgar Suter. Zürich/Basel, pp. 271-288. Köln: Köppe

Pasch, Helma 2000

'Es begann mit einem Zwergflusspferd. Zum Gebrauch der offiziellen afrikanischen Sprachen als schriftliche Medien.' In: „Mehr als nur Worte ... "Afrikanistische Beiträge zum 65. Geburtstag von Franz Rottland, ed. by Rainer Vossen et al., pp. 565-582. Köln: Köppe

Pasch, Helma 2005

'Westermann, Diedrich', in: Biographisch-Bibliographisches Kirchenlexikon,

Nordhausen: Verlag Traugott Bautz, http://www.bautz.de/bbkl/w/westermann d h.shtml (28.05.2006)

Philips, John Edward 1996

Hausa orthography in the twentieth century, Part I: Romanization, http://www.aa.tufs.ac.jp/ P aflang/TEXTS/sept96/philips.txt (15.04.2006)

Pilaszewicz, Stanislaw 2001

'History of the Dagomba Kingdom in some Hausa Ajami Manuscripts,' SDALC (Studies of the Department of African Languages and Cultures) 30:24-48

Prah, Kwesi 1997

'L'interaction culturelle entre la culture arabe et les autres cultures,' paper presented at the Arab League Educational, Cultural and Scientific Organization (ALECSO), Tunis 1997 (cit in Prah 2004)

Prah, Kwesi 2004

'Towards a strategic geopolitic vision of Afro-Arab relations,' holler Africa, http://www.hollerafrica.com/showArticle.php?catld=1\&artld=164\&PHPSESSID=8c0c0e0 3957cf0736faa1df5c50f4f2a (04.09.2006)

Qubee on the Web, s.d.

'Qubee handhuraa keenya,' Qubee on the Web - Qubee Intarneettii $d t$, http://www.qubee.org (15.05.2006)

Reh, Mechthild, 2005

'Multilingual writing: A reader-orientated typology - with examples from Lira Municipality (Uganda).' International Journal of the Sociology of Language 170:1-41

Rilly, Claude 04.2004

'The linguistic position of Meroitic', ARKAMANI Sudan Journal of Archaeology and Anthropology, An Arabic/English Review on Archaeological and Anthropological 
Research in the Sudan, http://www.arkamani.org/arkamani-library/meroitic/rilly.htm (25.04.2006)

Rosenau, Eugene V. (ed.) 1980

Sango-English Dictionary. Sibut/CAR:La Presse Biblique Paptiste \& Cleveland/Ohio: Baptist Mid-Missions

Rowan, Kirsty 2006

'A phonological investigation into the Meroitic 'syllable' signs - ne and se and their implications on the e sign', SOAS Working Papers in Linguistics 14:131-167, http://www.soas.ac.uk/lingfiles/workingpapers/rowan1.pdf\#search=\%22\%22nubian $\% 20$ s cript $\% 22 \% 22$

Samarin, William J. 1989a

'Colonization and pidginization on the Ubangi River.' Journal of African Languages and Linguistics 4:1-82

Samarin, William J.1989b

The Black Man's Burden. African Colonial Labor on the Congo and Ubangi Rivers, 18801900. Boulder, San Francisco \& London: Westview Press

Schaff, Philip 1819-1893 [1951]

'Africa. A continent as a whole.' In: The New Schaff-Herzog Encyclopedia of Religious

Knowledge, Vol. I: Aachen - Basilians. Grand Rapids: Christian Classics Ethereal

Library; Grand Rapids, MI: Baker Book House, 1951,

http://www.ccel.org/ccel/schaff/encyc01.iii.i.africa.html (01.05.2006)

Schenkel, Wolfgang [1983] ${ }^{3} 1998$

'Wozu die Ägypter eine Schrift brauchten.' In: Schrift und Gedächtnis. Archäologie der literarischen Kommunikation I, hrsg. von A. \& J. Assmann und Chr. Hardmeier, pp. 4564. München: Wilhelm Fink Verlag

Schmitt, Alfred 1963

Die Bamum-Schrift. Band I: Text. Wiesbaden: Harrassowitz

Scribner, Sylvie 1981

'Cultures and Textbooks,' in: The Textbook in American Society. A Volume Based on a Conference at the Library of Congress on May 2-3, 1979, ed. by John Y. Cole, Washington: Library of Congress, http://www.loc.gov/catdir/toc/becites/cfb/80027657.html\#cultures (01.05.2006)

Scribner, Sylvia and Michael Cole [1981] 1986

The Psychology of Literacy. London: Harvard University Press.

SEI (Script Encoding Initiative), online 'Bamum, SID 008,' http://www.linguistics.berkeley.edu/sei/USR.html\#n8, ed. by the Department of Linguistics, University of California, Berkeley (28.09.2006)

SIL 2003

'Sites on Scripts and Writing Systems ', NRSI: Computers \& Writing Systems, SIL international,

http://scripts.sil.org/cms/scripts/page.php?site id=nrsi\&item id=SitesOnScriptsAndWSs \#f5cd2629 (17.05.2006)

SIL, online

Akobêla awü töngana nye? Bangui: Société Internationale de Linguistique and

Secretariat d'Etat de la Recherche Scientifique et Technique

Skattum, Ingse 2000

'Le bambara écrit à l'école fondamentale', Nordic Journal of African Studies 9,3:108-132, http://www.njas.helsinki.fi/pdf-files/vol9num3/skattum.pdf (02.09.2006)

Simmons, David 2000 [2005] 
'Signs of the Times: Missionaries and Tribal Genesis in Southern Rhodesia', Transforming Anthropology 9,2:3-18, posted online on April 12, 2005 http://www.anthrosource.net/doi/abs/10.1525/tran.2000.9.2.3;jsessionid=n-2fcjENnx7ailoMV?cookieSet=1\&journalCode=tran

Somalinet, online http://www.somalinet.com/library/osmaniya/ (17.07.2006)

sozoala.com, online

'Le 29 mars 1959 disparaissait Barthélemy Boganda Président-Fondateur de la République Centrafricaine Témoignage de Monsieur Georges Yakité', http://www.sozoala.com/bb/georgesyakite.htm (29.09.2006)

Tandafor, Mirabel Azangeh 2006

'Project launched to conserve Bamum scripts,' L'Effort Camerounais. Com Newspaper of the Nationa Bishops' Conference of Cameroon, March 2006, http://www.leffortcamerounais.com/2006/03/project launche.html (28.09.2006)

Tisserant 1950

Sango, langue véhiculaire de l'Oubangui-Chari. Issy les-Moulineaux: Les Presses Missionnaires

Thornell, Christina 1994

'Reflections on the 1984 Sango orthography decree'. In: Pasch (ed.) Standardisierung internationaler afrikanischer Verkehrssprachen, pp. 33-57. Opladen: Westdeutscher Verlag

Thaly, Dominique 2005

'Niger: «Sauberkeit ist die Hälfte des Glaubens!»' Epo - Entwicklungspolitik online, http://www.epo.de/index.php?option=com content\&task=view\&id=101\&ltemid $=68$ (04.09.2006)

Trenel, Régis, Jean-Paul Hoch, Gaston Dongoï 1982 Sêndâmâti - Mathématiques. Ngbanga tî ânyîlikôlo tî Da tî Ûse fängö-yê - à l'usage des élèves de 6e Paris: SELAF \& ACCT

Tuchscherer, Konrad 1999

'The lost script of the Bagam.' African Affairs 98:55-77

UMich (University of Michigan) Papyrus Collection, online

'Demotic', in: 'Writing in Graeco-Roman Egypt', exhibit presented online by the University of Michigan Papyrus Collection, http://www.lib.umich.edu/pap/exhibits/writing/demotic.html (28.09.2006)

Unesco 2004a

'Choosing a script', International MOTHER language day 21 February 2004, http://portal.unesco.org/education/en/ev.phpURL ID=28343\&URL DO=DO TOPIC\&URL SECTION=201.html (01.05.2006)

Unesco 2004b

'Initiative B@bel and Script Encoding Initiative Supporting Linguistic Diversity in Cyberspace', News Archive 2004. UNESCO Communication and Information Resources, http://portal.unesco.org/ci/en/ev.php-

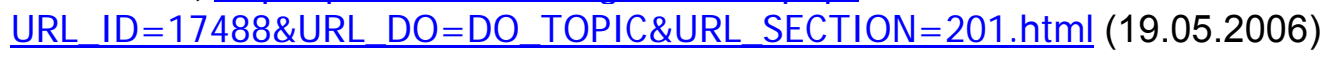

Veit-Wild, Flora 1984

'"Ich höre zu, wie Wörter meinem Bewußtsein entspringen": Anmerkungen aus Zimbabwe zum Verhältnis von Sprache und Literatur im nachkolonialen Afrika', in: Osnabrücker Beiträge zur Sprachtheorie, 25:104-112

Vinck, Honoré 1996 
'L'influence des missionaire sur la prise de conscience ethnique et politique des Mongo (R.D.C.)* 1925-1965', Revue Africaine des Sciences de la Mission (Kinshasa) 4:131147, http://www.aequatoria.be/French/Influence.html (19.05.2006)

Watchtower, online

'A-Témoin ti Jéhovah,' Official Web Site of Jehovah's Witnesses,

http://www.watchtower.org/languages/sg/index.html (19.05.2006)

Wikipedia $\rightarrow$ fr.wikipedia

'Mandombe', http://fr.wikipedia.org/wiki/Mandombe (25.05.2006)

Woldemikael, Tekle M. 2003

'Language, education and public policy in Eritrea', African Studies Review, April 2003, http://www.findarticles.com/p/articles/mi qa4106/is 200304/ai n9219176 (01.05.2006)

YSB = Yângâ tî Sahngo tî Bêafrîka

http://sango.free.fr/ (01.10.2006)

Yuntenwi, Isidor 2006

Colonialism, Heritage and Socio-Cultural Change: An Assessment of the Impact of Colonialism on Cultural Heritage and Sociocultural Practices of sub-Saharan Africa. M.A. thesis. Brandenburgische Technische Universität, Cottbus, http://www.sozum.tucottbus.de/Lehrstuhltexte/abschlussarbeiten/MA Thesis Yuntenwi.pdf\#search=\%22shu mum\%20bamum\%22 (26.09.2006)

ziva (zimbabwe institute of vigital arts) 2000

http://www.ziva.org.zw/afrikan.htm (17.05.2006)

* I am indebted to Anne Storch, Uschi Drolc, Christine Waag, Dirk Otten and Konrad Tuchscherer for many useful information and comments, but responsibility for errors is all mine.

1 Conditions of life should be improved in particular with regard to health keeping knowledge and nutrition. In many cases missionaries cooperated with colonial powers and were accused of helping the latter to exploit the Africans. Those missionaries who tried to protect Africans against the severe treatment of colonial administrators and representatives of economic enterprises often did not have the power to achieve their goals. These two terms are considered synonyms and will be used alternately.

School education ist strict in French (Uschi Drolc, p.c. Sept 2006)

"[...] ein Kontinent des gesprochenen Wortes, nicht des geschriebenen" (translation H.P.) Ostraca are potsherds and stone flakes bearing writing and/or depictions.

6 Syllabaries are sets of written symbols that represent (or approximate) syllables. A symbol in a syllabary typically represents a consonant and a vowel.

7 'Galla' is a designation for the Oromo by speakers of other languages. The Oromo call themselves Oromoo/Oromoota (sg/pl).

8 As for the author, Onesimos Nasib, s. Mekuria Bulcha (1995)

9 Mohamed VI. founded the institute by a royal decree from October $17^{\text {th }}, 2001$ (Kratochwil 2003:19).

10 'Ajami' designates Arabic writing for languages other than Arabic. The term is derived from an Arabic word meaning 'foreign person'. (PanAfrLoc).

11 As early as the $15^{\text {th }}$ century, literate West Africans began working out transcriptions for several of the region's most widespread languages in Arabic script (Easton \& Peach 1997b).

Later it was named "Fourah Bay College". Since 1966 it was a constituent college of the University of Sierra Leone. In 1972, a new act 'The University of Sierra Leone Act' was passed in parliament. This established a unitary system embracing Fourah Bay College (FBC), Njala University College and one or two other smaller colleges (FBC History). Löhr (1997:82) gives 1812 as the year of foundation, whereas on the FBCUS-website the year 1827 is given.

14 Tigre and Oromo have been graphized by European missionaries in Ge'ez, not in Roman script.

15 A short history of early African newspapers is given by BBC World Service (online) 
Landry \& Bourhis (1997) and Ben-Rafael et al. (2001) define 'linguistic landscape' as the tokens of environmental print found in the public domain. It includes advertisements, public announcements, road signs and inscriptions on buildings. "such an institution [as the Academia della Crusca in Italy and the Académie Française] was never installed in England. (Guillaume Schiltz 2004, ch.2.1)

The iconographic symbols used in Benin (formerly Dahomey) are not to be considered as a writing system (Delafosse 1899:295).

According to SIL the Vai Fonts were developed in 1999, LBTC gives the year 1996. The current version dates from August 2004.

Cf. the website of the Bassah Vah association: http://www.ie-inc.com/vkarmo/bcont.htm (17.05.2006)

Der Evangelische Heidenbote, a monthly of the Evangelical Missionary Society Basel (18281955) is accessible in the University Library Tübingen, shelf mark Gk II 57 a.4 (http://opac.ub.uni-tuebingen.de/cgi-bin/wwwolix.cgi?db=tzv\&nd=1563616, 17.05.2006 )

Yuntenwi (2006) confirms 1903 as the time of accruement and explicitly states that it is a legend which says that Sultan Njoya started the invention of the writing system around 1896 and completed it by 1903 .

The Studio for Transcultural Design-Creative Solutions, Vienna / Austria, http://www.members.aon.at/africanfonts.at/bamum1.htm (17.05.2006)

Sheng or Engsh if used, e.g. in the Kenyan blogs "Nairobi back in the day", and urban Kikongo is used in some forums of "Ne-Kongo" forums.

"Sheng represents code-mixing, which, as discussed below, is understood as a process that may produce an autonomous variety but has not yet done so." (Mufwene, online) All texts in Hausa on the web, e.g., are written in boko (Diki-Kidiri et al. 2003:35).

Diki-Kidiri (1977:13) claims that only in 1950 Latin orthography was replaced by French orthography, but Clerc's (1911) grammar is written in French orthography.

The success was such that the Bible Society, over the protest of whom the Grace Brethren Mission had the New Testament printed in French orthography, thirty years later congratulated those who had insisted on the French orthography, and would have no other for the 1965 Sango Bible.

For more information on Catholic and Protestant Sango cf. Pasch 1994.

During my fieldwork in 1990/91 I found only very few texts edited prior to 1980 .

Bouquiaux et al. (1978:24f) cite from the "Mémoir sur l'orthographe du sango" by a representative of the Bible Societies a table of four orthographies (Protestants, Radio, Catholics, Bible Societies) to which they added their own proposed orthography and the phonemic writing on which it is based.

In 1968 Bouquiaux (cit. from (Diki-Kidiri 1982:20-22) had proposed a similar orthography, indicating, however, vowel quality by diaeresis and not by accent $\langle a, \ddot{e}, e, i, \ddot{o}, o, u>$ for $/ a, \mathcal{E}$, $e, i, 0,0, u /$.

In Central African Republic they call themselves Èvangélique des Frères Information by Members of the Baptist Mid-Mission during my visit to Bangui in 1991.

\begin{tabular}{|l|l|l|l|l|l|l|l|l|}
\hline Ndo & ti & a & tourougou. & Zo & a & li & kirikiri & pepe \\
\hline place & of & pl & soldiers & person & 3s & enter & anyhow & NEG \\
\hline
\end{tabular}

Founder of the CAR. 